\title{
The Road to Developing Economically Feasible Plans for Green, Comfortable and Energy Efficient Buildings
}

\author{
Seyedeh Farzaneh Mousavi Motlagh ${ }^{1}\left(\mathbb{C}\right.$, Ali Sohani ${ }^{2}\left(\mathbb{D}\right.$, Mohammad Djavad Saghafi $^{1}$, Hoseyn Sayyaadi ${ }^{2}(\mathbb{C}$ \\ and Benedetto Nastasi ${ }^{3, *}$ (D) \\ 1 Department of Architecture, Architecture School, College of Fine Arts, University of Tehran, \\ 1415564583 Tehran, Iran; farzanehmousavim@gmail.com (S.F.M.M.); djsaghafifr@yahoo.fr (M.D.S.) \\ 2 Lab of Optimization of Thermal Systems' Installations, Faculty of Mechanical Engineering-Energy Division, \\ K.N. Toosi University of Technology, P.O. Box: 19395-1999, No. 15-19, Pardis St., Mollasadra Ave., Vanak Sq., \\ 1999143344 Tehran, Iran; alisohany@yahoo.com (A.S.); sayyaadi@kntu.ac.ir (H.S.) \\ 3 Department of Planning, Design, Technology of Architecture, Sapienza University of Rome, Via Flaminia 72, \\ 00196 Rome, Italy \\ * Correspondence: benedetto.nastasi@outlook.com
}

check for updates

Citation: Mousavi Motlagh, S.F.; Sohani, A.; Djavad Saghafi, M.; Sayyaadi, H.; Nastasi, B. The Road to Developing Economically Feasible Plans for Green, Comfortable and Energy Efficient Buildings. Energies 2021, 14, 636. https://doi.org/ $10.3390 /$ en14030636

Academic Editor: Jae-Weon Jeong

Received: 4 January 2021

Accepted: 24 January 2021

Published: 27 January 202

Publisher's Note: MDPI stays neutra with regard to jurisdictional claims in published maps and institutional affiliations.

Copyright: (c) 2021 by the authors. Licensee MDPI, Basel, Switzerland. This article is an open access article distributed under the terms and conditions of the Creative Commons Attribution (CC BY) license (https:/ / creativecommons.org/licenses/by/ $4.0 /)$

\begin{abstract}
Owing to the current challenges in energy and environmental crises, improving buildings, as one of the biggest concerns and contributors to these issues, is increasingly receiving attention from the world. Due to a variety of choices and situations for improving buildings, it is important to review the building performance optimization studies to find the proper solution. In this paper, these studies are reviewed by analyzing all the different key parameters involved in the optimization process, including the considered decision variables, objective functions, constraints, and case studies, along with the software programs and optimization algorithms employed. As the core literature, 44 investigations recently published are considered and compared. The current investigation provides sufficient information for all the experts in the building sector, such as architects and mechanical engineers. It is noticed that EnergyPlus and MATLAB have been employed more than other software for building simulation and optimization, respectively. In addition, among the nine different aspects that have been optimized in the literature, energy consumption, thermal comfort, and economic benefits are the first, second, and third most optimized, having shares of $38.6 \%, 22.7 \%$, and $17 \%$, respectively.
\end{abstract}

Keywords: daylighting; economic benefits; environmental impact; multi-objective simulation-based optimization; retrofitting building energy consumption; thermal-visual comfort

\section{Introduction}

During recent years, the standard of living has raised increasingly [1-4]. Moreover, the issues such as energy and environmental crises have led to growing concerns about the future of human-beings on the planet [5-8]. Since there are a lot of buildings in different applications all around the world, any improvement in the building sector, in which all the previously mentioned parameters are involved, is greatly appreciated by the entire world [9-11]. Different experts, including architects, energy engineers, mechanical engineers, etc., with different points of view, corporate in the design process [12]. This means that acquiring a desirable condition is a really challenging matter [13-16]. As a solution, optimization approaches, which are systematic ways to deal with such problems, have been increasingly applied [17].

Depending on the project goal and expected requirements, single-objective optimization (SOO) or multi-objective optimization (MOO) can be employed. In SOO, only one objective is minimized or maximized, whereas in MOO two or more than two objective functions are enhanced, simultaneously.

Optimization problems can be categorized in different ways, for example, based on the optimized objective functions, considered decision variables or constraints, and so on. 
In order to perform further studies, being well informed about the investigations done in the past is of great importance. The more comprehensive information provided from the literature, the higher quality the future studies will be.

Investigating the review studies in the field of building performance optimization (BPO) clarified that, despite providing valuable information, these studies also have some drawbacks. The main drawbacks of the review articles done recently are collected in Table 1.

Table 1. List of the recent review studies in the field of building performance optimization (BPO).

\begin{tabular}{ccl}
\hline Study & Year & \multicolumn{1}{c}{ The Main Drawbacks } \\
\hline Wong and Zhou [18] 2015 & $\begin{array}{l}\text { The research aimed to provide an overview of the ways to improve buildings environmental } \\
\text { sustainability in their life cycle. The studies that optimized other objectives were } \\
\text { not investigated. }\end{array}$ \\
\hline Carlucci et al. [19] $2015 \quad \begin{array}{l}\text { Visual comfort definitions, and its constraints and indicators were well defined; however, } \\
\text { details about other building aspects, decision variables, employed algorithms, and software } \\
\text { were not reported. }\end{array}$
\end{tabular}

- $\quad$ This paper discussed the literature from the architectural perspective. Other perspectives were not taken into account.

Shi et al. [20] 2016 - The investigation did not classify different optimization approaches.

- The constraints imposed to the optimization problems were not mentioned.

- $\quad$ Studies which employed both MOO and SOO were not compared to the ones which conducted either MOO or SOO.

- Only a brief description about the previous review studies was presented. It means that the research papers were not taken into account.

Bonyadi and Michalewicz [21]

- The review was limited to the particle swarm algorithm; other algorithms were not taken 2017 into account.

- $\quad$ MOO problems were not studied.

- The information about decision variables, constraints, and other key parameters in an optimization problem were not presented.

\begin{tabular}{lll} 
Kumar et al. [22] $2017 \quad$ - Methods and software programs were the only investigated parameters. \\
\hline Tian et al. [23] $2018 \quad \begin{array}{l}\text { - The review merely covered passive design buildings. } \\
\text { There is the lack of reviewing decision variables, objective functions, constraints, software, } \\
\text { and so on. } \\
\text { The review was written from the architectural point of view and there is no sufficient } \\
\text { information for the other experts. }\end{array}$
\end{tabular}

- Among all the key parameters, only the building aspects which were considered as the

Ekici et al. [24] $2019 \quad$ objectives were discussed.

- Among evolutionary, juts swarm algorithms were investigated.

- The consideration of decision variables was restricted to form-finding ones.

Alothaimeen and Arditi [25] 2019

- SOO studies were not reviewed.

- The investigated MOO publications were in the range of 2012-2016, which is not up to date.

- Explanations about some important parameters of an optimization problem, such as the considered decision variables and employed software programs were not given.
Joench et al. [26] 2019
- The paper was dedicated to review the optimization methods; there was no explanation about other involved aspects including the considered objective functions, decision variables, constraints, etc. 
Considering the mentioned gap of study, which can be identified from Table 1, in this paper, the investigations done in the field of $\mathrm{BPO}$ are discussed from different viewpoints:

- The optimization problems are classified to $\mathrm{SOO}$ and $\mathrm{MOO}$, and they are compared to each other. In addition, the studies that evaluated both $\mathrm{SOO}$ and $\mathrm{MOO}$ are also taken into account.

- All the key parameters in an optimization problem are considered and the investigations are analyzed based on each of them, separately. The key parameters include objective functions, decision variables, and constraints. There have been nine different aspects from which objective functions have been selected so far. The review investigates all the nine aspects completely and in detail.

- The studies are also categorized and investigated based on other criteria, such as optimization algorithms and software programs. Moreover, software programs are divided into building simulation-based and optimization tools.

- The review is written in a way that it provides information for not only architects but also other experts in the building sector.

Therefore, this study serves as a reference to acquire brief but detailed information for researchers in the future to achieve better results in their further studies. Having the information about the previously done investigations reported in this review will help the researchers who are going to conduct $\mathrm{BPO}$ studies to select the key parameters in a more efficient and comprehensive way. Moreover, they will not forget some points which make the optimization results unfavorable from some aspects.

This paper has the following structure. After this part, i.e., the introduction, the core literature is introduced. Then, it is analyzed from different aspects, including the considered objective functions, decision variables, constraints, and the case study. Next, the algorithms employed for optimization and the software used are reviewed, and after that, conclusions are presented.

\section{Paper Searching Methodology}

This review concentrates on investigations within the building performance optimization (BPO) framework found from Scopus and Science Direct databases. Since the optimization algorithms and computer infrastructure have been significantly enhanced during these years, the studies done in the years before 2015 were usually simple, and for that reason, only recent studies that were published in the period of 2015 to 2019 were taken into account. Moreover, some keywords, such as "multi-objective optimization", "single-objective optimization", "simulation-based optimization", "zero-energy buildings", "energy consumption", "thermal comfort", "daylighting", "visual comfort", and "life cycle cost" were used to select the relevant studies. This search method resulted in collecting 44 studies that were considered as the core literature.

\section{Overview of the Studies Selected}

Here, a general classification of the core literature is presented based on the year and the optimization approach. As is seen in Table 2, two different approaches have been followed in the optimization processes of these studies, including single-objective optimization (SOO) and multi-objective optimization (MOO). Moreover, in some of the reviewed studies, the results of these two approaches have been compared with each other. Such investigations are presented in the category of "single-objective versus multi-objective approach" in Section 3.3. 
Table 2. The core literature.

\begin{tabular}{|c|c|c|c|}
\hline \multirow{2}{*}{ Study } & \multirow{2}{*}{ Year } & \multicolumn{2}{|c|}{ Optimization Approach } \\
\hline & & SOO & MOO \\
\hline Abdallah and El-Rayes [27] & 2015 & $\sqrt{ }$ & \\
\hline Mangkuto et al. [28] & 2016 & $\sqrt{ }$ & \\
\hline Ferdyn-Grygierek and Grygierek [29] & 2017 & $\sqrt{ }$ & \\
\hline Baglivo et al. [30] & 2017 & $\sqrt{ }$ & \\
\hline Bamdad et al. [31] & 2017 & $\sqrt{ }$ & \\
\hline Zhou et al. [32] & 2018 & $\sqrt{ }$ & \\
\hline Li et al. [33] & 2018 & $\sqrt{ }$ & \\
\hline Sghiouri et al. [34] & 2018 & $\sqrt{ }$ & \\
\hline Xue et al. [35] & 2019 & $\sqrt{ }$ & \\
\hline Echenagucia et al. [36] & 2015 & & $\sqrt{ }$ \\
\hline Yu et al. [37] & 2015 & & $\sqrt{ }$ \\
\hline Carlucci et al. [38] & 2015 & & $\sqrt{ }$ \\
\hline Ascione et al. [39] & 2015 & & $\sqrt{ }$ \\
\hline Zhang et al. [40] & 2016 & & $\sqrt{ }$ \\
\hline Gadelhak and Lang [41] & 2016 & & $\sqrt{ }$ \\
\hline Pan et al. [42] & 2016 & & $\sqrt{ }$ \\
\hline Ascione et al. [43] & 2017 & & $\sqrt{ }$ \\
\hline Bingham et al. [44] & 2017 & & $\sqrt{ }$ \\
\hline Zhang et al. [45] & 2017 & & $\sqrt{ }$ \\
\hline Mostavi et al. [46] & 2017 & & $\sqrt{ }$ \\
\hline Bre and Fachinotti [47] & 2017 & & $\sqrt{ }$ \\
\hline Hamdy and Mauro [48] & 2017 & & $\sqrt{ }$ \\
\hline Wu et al. [49] & 2018 & & $\sqrt{ }$ \\
\hline Lin et al. [50] & 2018 & & $\sqrt{ }$ \\
\hline Grygierek and Ferdyn-Grygierek [51] & 2018 & & $\sqrt{ }$ \\
\hline Schito et al. [52] & 2018 & & $\sqrt{ }$ \\
\hline Gou et al. [53] & 2018 & & $\sqrt{ }$ \\
\hline Harkouss et al. [54] & 2018 & & $\sqrt{ }$ \\
\hline Sohani et al. [55] & 2019 & & $\sqrt{ }$ \\
\hline Zemero et al. [56] & 2019 & & $\sqrt{ }$ \\
\hline Yi [57] & 2019 & & $\sqrt{ }$ \\
\hline Hong et al. [58] & 2019 & & $\sqrt{ }$ \\
\hline Kirimtat et al. [59] & 2019 & & $\sqrt{ }$ \\
\hline Ascione et al. [60] & 2019 & & $\sqrt{ }$ \\
\hline Zhai et al. [61] & 2019 & & $\sqrt{ }$ \\
\hline Si et al. [62] & 2019 & & $\sqrt{ }$ \\
\hline Sharif and Hammad [63] & 2019 & & $\sqrt{ }$ \\
\hline Fang and Cho [64] & 2019 & & $\sqrt{ }$ \\
\hline Sohani et al. [65] & 2019 & & $\sqrt{ }$ \\
\hline Lu et al. [66] & 2015 & $\sqrt{ }$ & $\sqrt{ }$ \\
\hline Delgarm et al. [67] & 2016 & $\sqrt{ }$ & $\sqrt{ }$ \\
\hline Delgarm et al. [68] & 2016 & $\sqrt{ }$ & $\sqrt{ }$ \\
\hline Delgarm et al. [69] & 2016 & $\sqrt{ }$ & $\sqrt{ }$ \\
\hline Xiong et al. [70] & 2019 & $\sqrt{ }$ & $\sqrt{ }$ \\
\hline
\end{tabular}

As is shown in Figure 1, about 30\% of the selected studies were done in 2019. This demonstrates that there is a growing interest in the BPO topics among researchers worldwide.

\subsection{Single-Objective Optimization (SOO)}

In the optimization process, based on the SOO approach, only one aspect is optimized. In order to achieve better results, the researcher may consider other aspects than the constraints which are very likely to have the readers confused with the objective functions (e.g., [27,30,33,35]). It should be noted that Mangkuto et al. [28] claimed the MOO approach was proposed in their paper. In fact, in that paper, in the optimization process minimizing lighting energy demand was subjected to the limitation of five daylight indicators. This 
means that lighting energy demand was the only objective function, and the five daylight indicators were the constraints of the SOO.

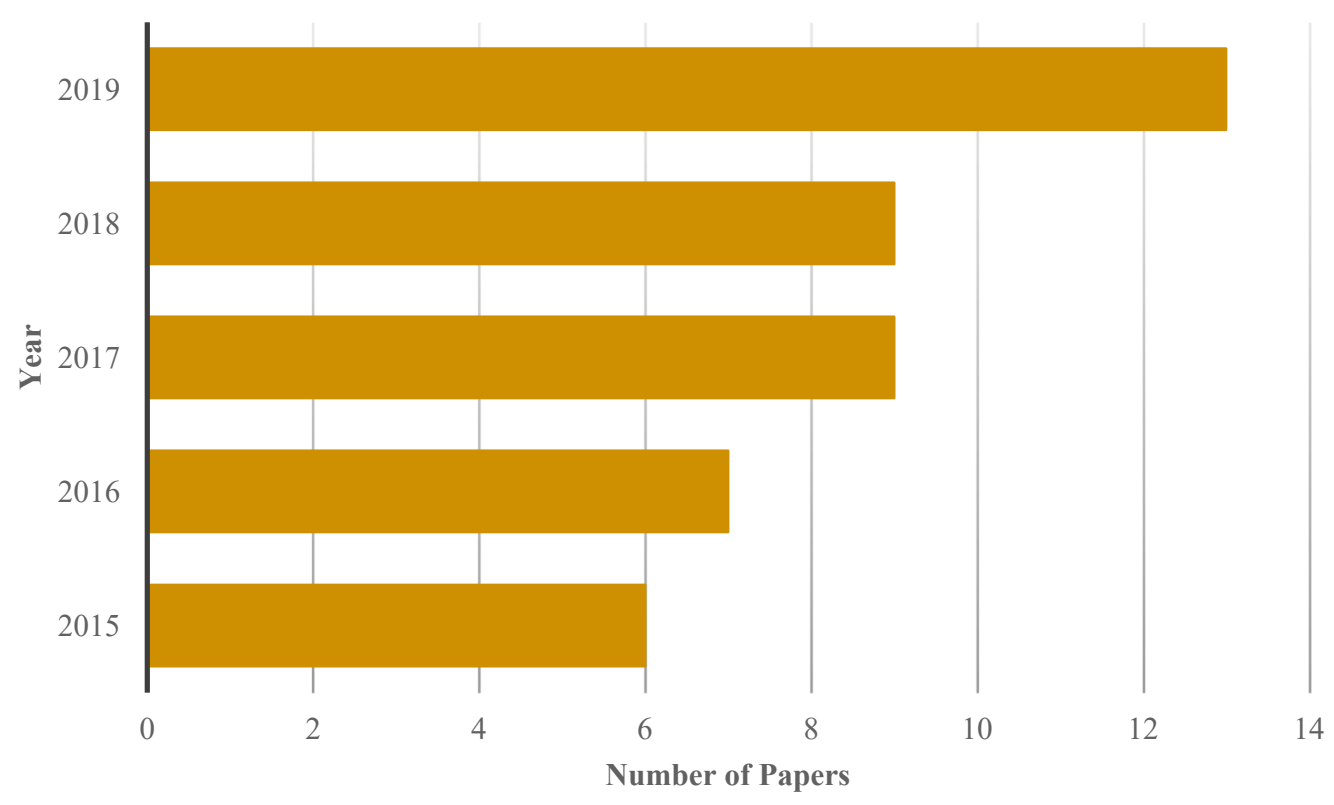

Figure 1. Comparing the number of applicable studies done in each year.

\subsection{Multi-Objective Optimization (MOO)}

$\mathrm{MOO}$ is used to optimize different objectives at the same time. Reviewing the studies belong to this group shows that, in such investigations, two, three, or four objectives were optimized simultaneously. In order to choose the objective functions, three different types of approaches have been employed:

- Type 1: optimizing two or more than two indicators of one aspect (e.g., [36,40]);

- Type 2: optimizing one indicator of two or more than two aspects (e.g., $[37,39,41])$;

- $\quad$ Type 3: a mixture of both (e.g., $[38,55,57])$.

Figure 2 represents that the majority of the reviewed studies, with the share of $77 \%$, employed type 2 of MOO.

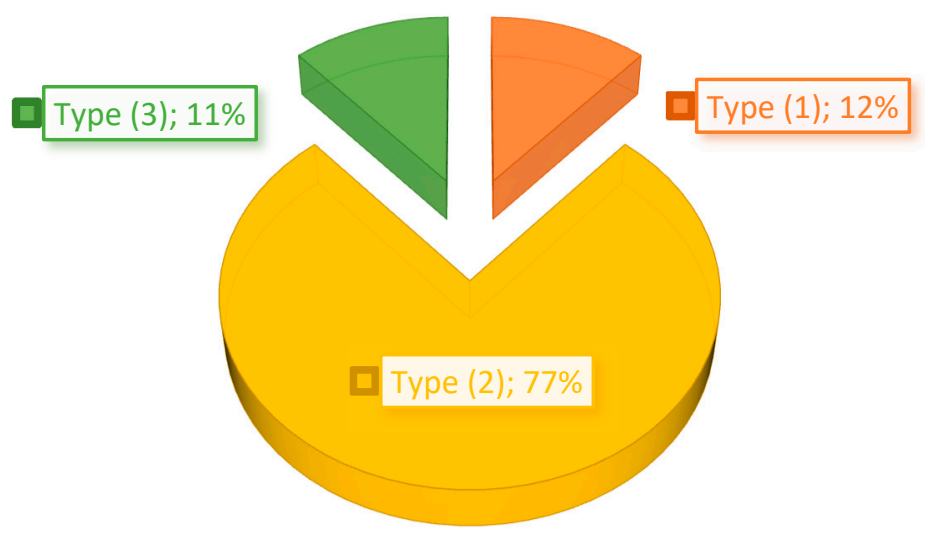

Figure 2. Share of different types of multi-objective optimization (MOO) in the core literature.

\subsection{Single-Objective Versus Multi-Objective Optimization}

In these studies, different objectives have been optimized independently by SOO. Since different objectives usually behave contrary to each other, the impact of other objectives might be considered as the constraints of $\mathrm{SOO}$ (e.g., [70]). On the other hand, $\mathrm{MOO}$ has 
been also conducted, and the results of SOO considering different objective functions are compared to the MOO outcome.

\section{Overview of the Selected Studies}

In this part, the core literature is analyzed based on three key parameters in an optimization process, namely, objective functions, decision variables, and constraints. As is shown in Figure 3, in the BPO procedure, there is a strong connection among these three parameters.

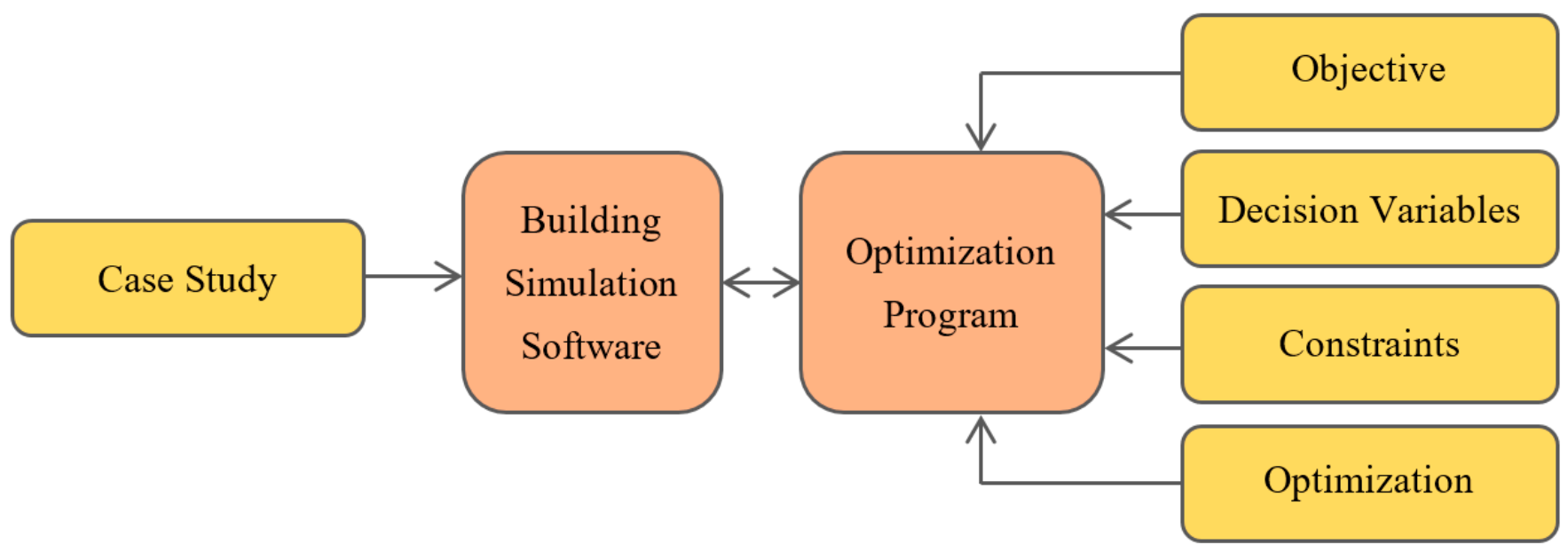

Figure 3. The BPO procedure.

\subsection{Objective Functions}

Reviewing the studies shows that nine different aspects have been considered in the optimization process. Each of these aspects has been assessed with some indicators, and the objective functions have been chosen among them. In the MOO approach, two or more than two indicators were chosen and defined. As it was mentioned in Section 3.2, these indicators might belong to the same aspects or not.

These aspects have been taken into account in the reviewed studies:

- $\quad$ Energy consumption (E.C);

- Thermal comfort (T.C);

- $\quad$ Economic benefit (E.B);

- Visual comfort (V.C);

- Environmental impact (E.I);

- $\quad$ Shape (S.);

- $\quad$ Artwork preservation risk (A.P.R);

- Aesthetical perception (A.P);

- Water consumption (W.C).

As it is shown in Figure 4, energy consumption indicators were the dominant objectives in the reviewed studies, accounting for $38.6 \%$. Thermal comfort and economic benefit indicators, with $22.7 \%$ and $17.0 \%$, were the second and third most-optimized objectives, respectively. The aspects and objective functions considered in each study are presented in Table 3. 


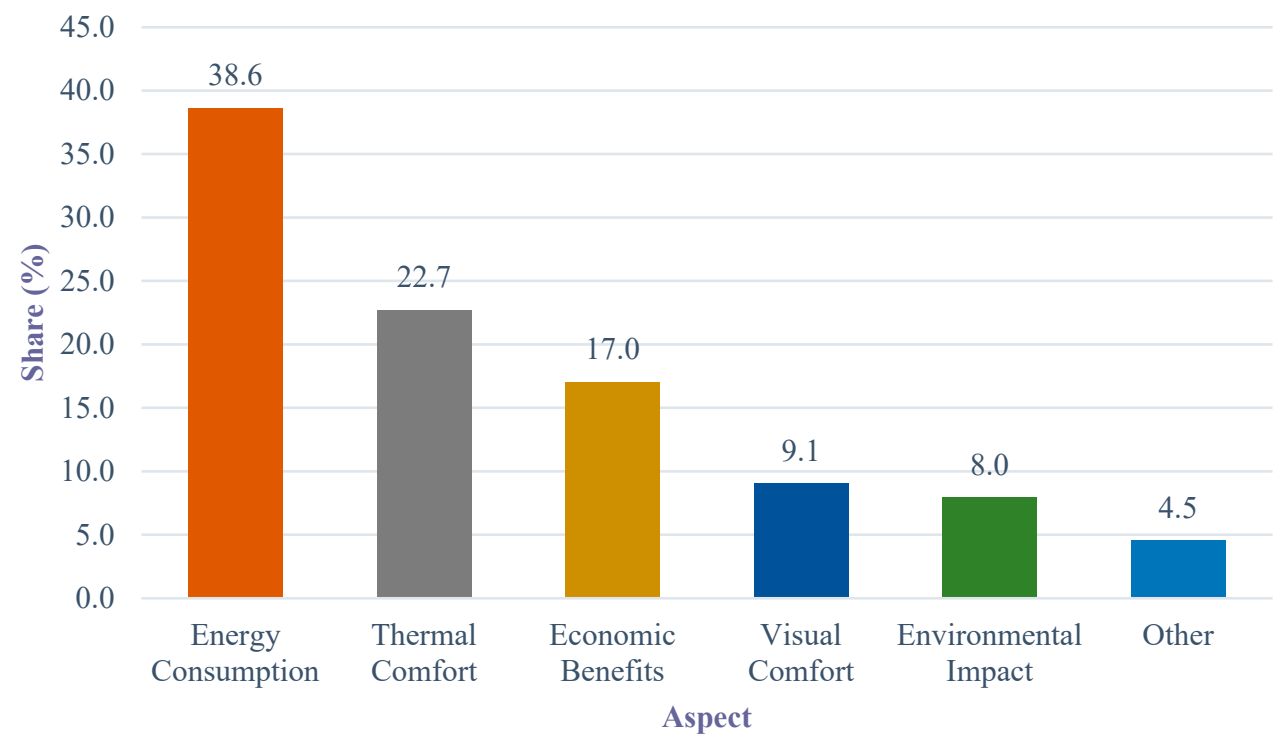

Figure 4. Share of each aspect in the optimization studies.

Table 3. The aspects which have been considered as the optimization objective functions in the core literature.

\begin{tabular}{|c|c|c|c|c|c|c|c|c|c|}
\hline \multirow{2}{*}{ Study } & \multicolumn{8}{|c|}{ Considered Aspect } & \multirow{2}{*}{ Objective Function } \\
\hline & E.C & T.C & E.B & V.C & E.I & S. & A.P.R A.P & W.C & \\
\hline Abdallah and El-Rayes [27] & & & & & $\checkmark$ & $\checkmark$ & & & $\begin{array}{l}\text { Min. Building Environmental } \\
\text { Impacts Index }\end{array}$ \\
\hline Mangkuto et al. [28] & $\checkmark$ & & & & & & & & $\begin{array}{l}\text { Min. Total Annual Lighting } \\
\text { Energy Demand }\end{array}$ \\
\hline $\begin{array}{l}\text { Ferdyn-Grygierek and } \\
\text { Grygierek [29] }\end{array}$ & & & $\checkmark$ & & & & & & Min. Life-Cycle Cost \\
\hline Baglivo et al. [30] & & $\checkmark$ & & & & & & & Opt. The Operative Temperature \\
\hline Bamdad et al. [31] & $\checkmark$ & & & & & & & & $\begin{array}{l}\text { Min. Annual End Use } \\
\text { Energy Consumption }\end{array}$ \\
\hline Zhou et al. [32] & $\checkmark$ & & & & & & & & $\begin{array}{l}\text { Min. Annual Heating } \\
\text { Energy Consumption }\end{array}$ \\
\hline Li et al. [33] & $\checkmark$ & & & & & & & & $\begin{array}{l}\text { Min. Total Energy Consumption } \\
\text { (Heating + Cooling + Lighting) }\end{array}$ \\
\hline Sghiouri et al. [34] & & $\checkmark$ & & & & & & & Min. Discomfort Degree-hours \\
\hline Xue et al. [35] & $\checkmark$ & & & & & & & & Min. Annual Cooling Load \\
\hline Echenagucia et al. [36] & $\checkmark$ & & & & & & & & $\begin{array}{l}\text { (1) Min. Heating Energy Need } \\
\text { (2) Min. Cooling Energy Need } \\
\text { Min. Lighting Energy Need }\end{array}$ \\
\hline Yu et al. [37] & $\checkmark$ & $\checkmark$ & & & & & & & $\begin{array}{l}\text { (1) Min. Annual Energy } \\
\text { Consumption. } \\
\text { (2) Max. Percentage of Thermal } \\
\text { Comfort Hours throughout } \\
\text { the Year }\end{array}$ \\
\hline
\end{tabular}


Table 3. Cont.

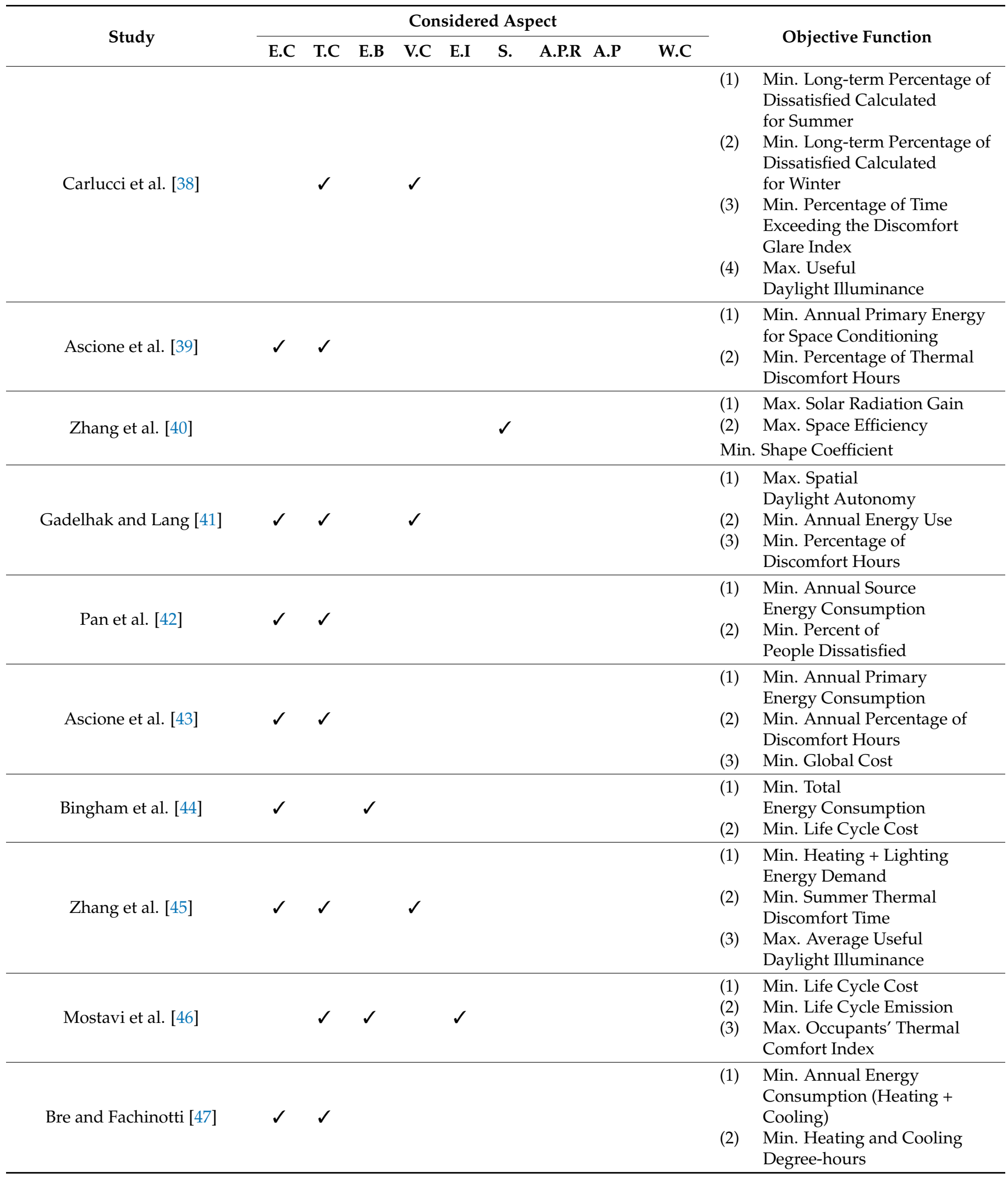


Table 3. Cont.

\begin{tabular}{|c|c|c|c|c|c|c|c|c|c|c|c|}
\hline \multirow{2}{*}{ Study } & \multicolumn{9}{|c|}{ Considered Aspect } & \multirow{2}{*}{\multicolumn{2}{|c|}{ Objective Function }} \\
\hline & E.C & T.C & E.B & V.C & E.I & S. & A.P.R & A.P & W.C & & \\
\hline Hamdy and Mauro [48] & & & $\checkmark$ & & $\checkmark$ & & & & & $\begin{array}{l}\text { (1) } \\
(2)\end{array}$ & $\begin{array}{l}\text { Min. Carbon Dioxide } \\
\text { Equivalent Emissions } \\
\text { Min. Discounted } \\
\text { Payback Time }\end{array}$ \\
\hline Wu et al. [49] & $\checkmark$ & & $\checkmark$ & & & & & & & $\begin{array}{l}(1) \\
(2)\end{array}$ & $\begin{array}{l}\text { Min. Life Cycle } \\
\text { Energy Consumption } \\
\text { Min. Life Cycle Cost }\end{array}$ \\
\hline Lin et al. [50] & $\checkmark$ & $\checkmark$ & & & & & & & & $\begin{array}{l}(1) \\
(2)\end{array}$ & $\begin{array}{l}\text { Min. Annual Cooling and } \\
\text { Heating Load } \\
\text { Min. Total Number of } \\
\text { Discomfort Degree Hours }\end{array}$ \\
\hline $\begin{array}{c}\text { Grygierek and } \\
\text { Ferdyn-Grygierek [51] }\end{array}$ & & $\checkmark$ & $\checkmark$ & & & & & & & $\begin{array}{l}(1) \\
(2)\end{array}$ & $\begin{array}{l}\text { Min. Life Cycle Cost } \\
\text { Min. Number of Hours with } \\
\text { Thermal Discomfort }\end{array}$ \\
\hline Schito et al. [52] & $\checkmark$ & $\checkmark$ & & & & & & & & $\begin{array}{l}\text { (1) } \\
(2) \\
(3)\end{array}$ & $\begin{array}{l}\text { Min. Total Energy Needs at } \\
\text { The HVAC System } \\
\text { Min. Predicted Percentage } \\
\text { of Dissatisfied } \\
\text { Max. Lifetime Multiplier }\end{array}$ \\
\hline Gou et al. [53] & $\checkmark$ & $\checkmark$ & & & & & & & & $\begin{array}{l}\text { (1) } \\
(2)\end{array}$ & $\begin{array}{l}\text { Min. Annual Energy Demands } \\
\text { for Heating and Cooling } \\
\text { Max. Annual Indoor Thermal } \\
\text { Comfort Time Ratio }\end{array}$ \\
\hline Harkouss et al. [54] & $\checkmark$ & & $\checkmark$ & & & & & & & $\begin{array}{l}(1) \\
(2)\end{array}$ & $\begin{array}{l}\text { Min. Electrical Consumption } \\
\text { Min. Life Cycle Cost }\end{array}$ \\
\hline Sohani et al. [55] & $\checkmark$ & & $\sqrt{ }$ & & & & & & & $\begin{array}{l}(1) \\
(2) \\
(3)\end{array}$ & $\begin{array}{l}\text { Min. Operating Cost } \\
\text { Min. Water Cost } \\
\text { Max. Energy Performance }\end{array}$ \\
\hline Zemero et al. [56] & $\checkmark$ & & $\checkmark$ & & & & & & & $\begin{array}{l}(1) \\
(2)\end{array}$ & $\begin{array}{l}\text { Min. Annual } \\
\text { Energy Consumption } \\
\text { Min. Constructive Cost }\end{array}$ \\
\hline Yi [57] & & & & $\checkmark$ & & & & $\checkmark$ & & $\begin{array}{l}(1) \\
(2) \\
(3)\end{array}$ & $\begin{array}{l}\text { Max. Average Value of Spatial } \\
\text { Daylight Autonomy } \\
\text { Min. Average Value of Annual } \\
\text { Sun Exposure } \\
\text { The Preference Look of a } \\
\text { Building Skin }\end{array}$ \\
\hline Hong et al. [58] & $\checkmark$ & $\checkmark$ & $\checkmark$ & & $\checkmark$ & & & & & $\begin{array}{l}(1) \\
(2) \\
(3)\end{array}$ & $\begin{array}{l}\text { Min. Predicted Mean Vote } \\
\text { Min. Initial Investment Cost } \\
\text { Min. Thermal Energy } \\
\text { consumption + Net Present } \\
\text { Value + Global } \\
\text { Warming Potential }\end{array}$ \\
\hline Kirimtat et al. [59] & $\checkmark$ & & & $\checkmark$ & & & & & & $\begin{array}{l}\text { (1) } \\
(2)\end{array}$ & $\begin{array}{l}\text { Min. Total Energy } \\
\text { Consumption } \\
\text { Max. Average Value of Useful } \\
\text { Daylight Illuminance }\end{array}$ \\
\hline Ascione et al. [60] & $\checkmark$ & $\checkmark$ & $\checkmark$ & & & & & & & $\begin{array}{l}(1) \\
(2) \\
(3)\end{array}$ & $\begin{array}{l}\text { Min. Primary Energy } \\
\text { Consumption } \\
\text { Min. Global Cost } \\
\text { Min. Discomfort Hours }\end{array}$ \\
\hline
\end{tabular}


Table 3. Cont.

\begin{tabular}{|c|c|c|c|c|c|c|c|c|c|c|}
\hline \multirow{2}{*}{ Study } & \multicolumn{8}{|c|}{ Considered Aspect } & \multirow{2}{*}{\multicolumn{2}{|c|}{ Objective Function }} \\
\hline & E.C & T.C & E.B & V.C & E.I & S. & A.P.R A.P & W.C & & \\
\hline Zhai et al. [61] & $\checkmark$ & $\checkmark$ & & $\checkmark$ & & & & & $\begin{array}{l}(1) \\
(2) \\
(3)\end{array}$ & $\begin{array}{l}\text { Min. Annual Total Energy } \\
\text { Consumptions for Heating, } \\
\text { Cooling and Lighting } \\
\text { Min. Total Number of } \\
\text { Discomfort Degree hours } \\
\text { Max. Useful } \\
\text { Daylight Illuminance }\end{array}$ \\
\hline Si et al. [62] & $\checkmark$ & $\checkmark$ & & & & & & & $\begin{array}{l}(1) \\
(2)\end{array}$ & $\begin{array}{l}\text { Min. Annual Energy Demand } \\
\text { for Cooling and Heating and } \\
\text { Artificial Lighting } \\
\text { Min. Annual Average } \\
\text { Predicted } \\
\text { Percentage Dissatisfied }\end{array}$ \\
\hline Sharif and Hammad [63] & $\checkmark$ & & $\checkmark$ & & $\checkmark$ & & & & $\begin{array}{l}(1) \\
(2) \\
(3)\end{array}$ & $\begin{array}{l}\text { Min. Global } \\
\text { Warming Potential } \\
\text { Min. Life Cycle Cost } \\
\text { Min. Total } \\
\text { Energy Consumption }\end{array}$ \\
\hline Fang and Cho [64] & $\checkmark$ & & & $\checkmark$ & & & & & $\begin{array}{l}\text { (1) } \\
\text { Min }\end{array}$ & $\begin{array}{l}\text { Max. Useful } \\
\text { Daylight Illuminance } \\
\text { Energy Use Intensity }\end{array}$ \\
\hline Sohani et al. [65] & $\checkmark$ & & $\checkmark$ & & $\checkmark$ & & & $\checkmark$ & $\begin{array}{l}(1) \\
(2) \\
(3) \\
(4)\end{array}$ & $\begin{array}{l}\text { Min. Life Cycle Cost } \\
\text { Min. Annual Carbon } \\
\text { Dioxide Emission } \\
\text { Min. Annual Water } \\
\text { Consumption } \\
\text { Max. Annual } \\
\text { Energy Performance }\end{array}$ \\
\hline Lu et al. [66] & $\checkmark$ & & $\checkmark$ & & $\checkmark$ & & & & $\begin{array}{l}(1) \\
(2) \\
(3)\end{array}$ & $\begin{array}{l}\text { Min. Total Cost } \\
\text { Min. Carbon } \\
\text { Dioxide Emissions } \\
\text { Min. Grid Interaction Index }\end{array}$ \\
\hline Delgarm et al. [67] & $\checkmark$ & & & & & & & & $\begin{array}{l}(1) \\
(2) \\
(3)\end{array}$ & $\begin{array}{l}\text { Min. Annual Heating } \\
\text { Electricity Consumption } \\
\text { Min. Annual Cooling } \\
\text { Electricity Consumption } \\
\text { Min. Annual Lighting } \\
\text { Electricity Consumption }\end{array}$ \\
\hline Delgarm et al. [68] & $\checkmark$ & $\checkmark$ & & & & & & & $\begin{array}{l}(1) \\
(2)\end{array}$ & $\begin{array}{l}\text { Min. Total Energy } \\
\text { Consumption. } \\
\text { Min. Predicted Percentage } \\
\text { Dissatisfied }\end{array}$ \\
\hline Delgarm et al. [69] & $\checkmark$ & & & & & & & & $\begin{array}{l}(1) \\
(2)\end{array}$ & $\begin{array}{l}\text { Min. Annual Cooling Energy } \\
\text { Consumption. } \\
\text { Min. Annual Lighting Energy } \\
\text { Consumption }\end{array}$ \\
\hline Xiong et al. [70] & $\checkmark$ & & & $\checkmark$ & & & & & $\begin{array}{l}(1) \\
(2)\end{array}$ & $\begin{array}{l}\text { Max. Satisfaction Utility } \\
\text { Max. Energy Saving }\end{array}$ \\
\hline
\end{tabular}

\subsubsection{Energy Consumption}

To the best of our knowledge, researchers have used 13 indicators to minimize energy consumption in buildings. These indicators are shown in Figure 5. In some studies (e.g., $[42,61,62])$, the three most used indicators, heating, cooling, and lighting energy 
consumption, have been optimized as one objective function, named the total energy demand. That is usually done to simplify the computational difficulties of the optimization process caused by the increase in the number of objective functions. In addition, for more simplification, the combination of two of these three indicators might be taken into account, depending on the parameters such as location and function of the case study. As an example to clarify the impact of climate on choosing the energy related objective functions, Zhang et al. [45], studied the performances of school buildings in the cold climate of China by investigating heating and lighting energy demands as one objective to describe the energy performance for thermal and visual comfort indicators. In that work, due to the climatic conditions, the energy demand for cooling was not considered.

Moreover, the function of the case study can also help to simplify the optimization process in temporarily occupied buildings, such as office buildings. This means that if the building is only occupied during the day, the main concerns are about cooling and lighting energy consumption. It should be pointed out that reviewing some other studies (e.g., $[36,67,69])$ has made it clear that the best condition is achieved while the energy demands for heating, cooling, and lighting are optimized together and independently. However, Mangkuto et al. [28], Zhou et al. [32], and Xue et al. [35], have optimized lighting, heating, and cooling energy demands using the SOO approach, respectively.

\subsubsection{Thermal Comfort}

Figure 6 shows the eight different indicators that have been taken into account in the reviewed studies to investigate thermal comfort. These indicators can also be assessed for different seasons, independently. In the work published by Carlucci et al. [38], the percentages of dissatisfied people in summer and winter were optimized as two independent objectives, using the MOO approach. In another study [30], the operative air temperature was considered as the thermal comfort-describing objective function. Based on the definition, the operative air temperature is dependent on the season. It means that in the cooling and heating periods, it should be minimized and maximized, respectively.

\subsubsection{Economic Benefit}

In the reviewed studies, the optimum solution for this aspect has been achieved by optimizing nine different indicators imposed on both SOO and MOO. Among all these indicators mentioned in Figure 7, life cycle cost has been the most optimized. In the process of evaluating the life cycle cost, the significance of minor costs such as water cost might be disregarded. To avoid that, Sohani et al. [55] considered operating costs and water costs separately.

\subsubsection{Visual Comfort}

Despite the importance of visual comfort to both occupants' behavior and energy use, only five indicators describing this aspect have been considered in the reviewed studies. These indicators are introduced in Figure 8. In the research done by Mangkuto et al. [28], other metrics such as daylight factor, uniformity, and daylight glare probability have been taken into account as the constraints imposed on the SOO.

\subsubsection{Environmental Impact}

The growing concern for the environmental impacts of buildings has built a strong urge in researchers to consider this aspect in the optimization studies. Figure 9 shows the four indicators used in the studies we reviewed. It should be noted that there is a huge difference between carbon dioxide emissions and the equivalent carbon dioxide emissions, as two of the four indicators that describe the environmental impact. In the equivalent carbon dioxide emissions, unlike carbon dioxide emissions, other types of emissions besides carbon dioxide have been also taken into account. 


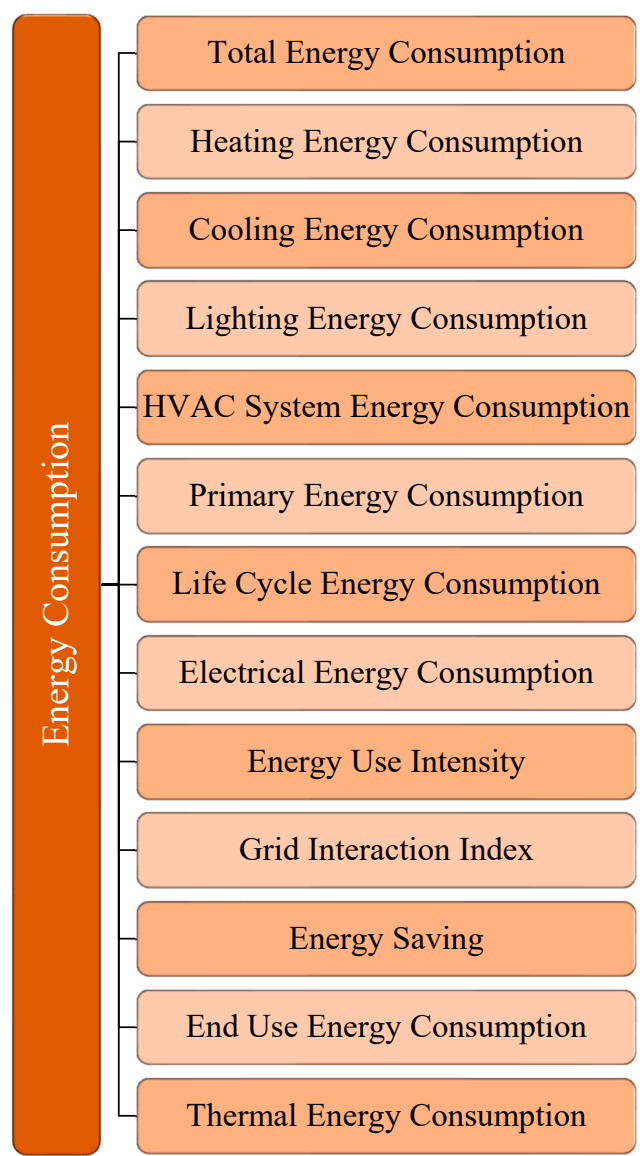

Figure 5. Energy consumption indicators.

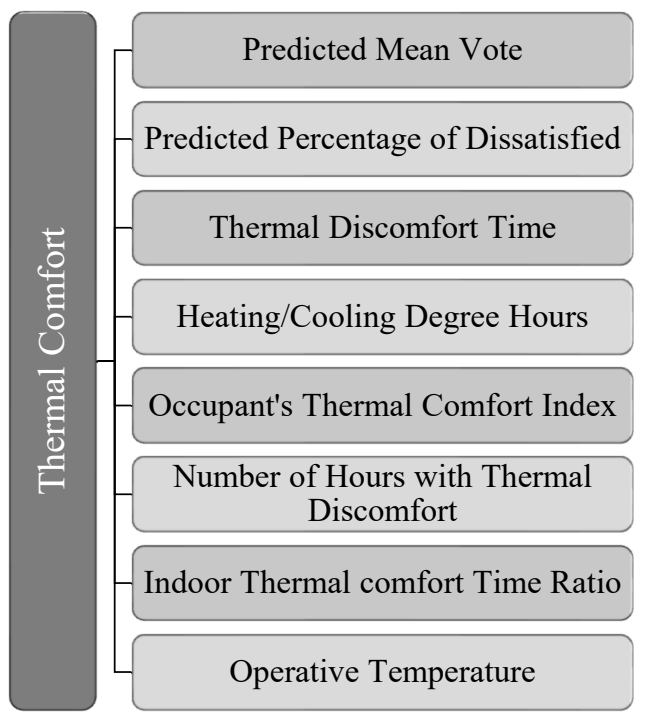

Figure 6. Thermal comfort indicators. 


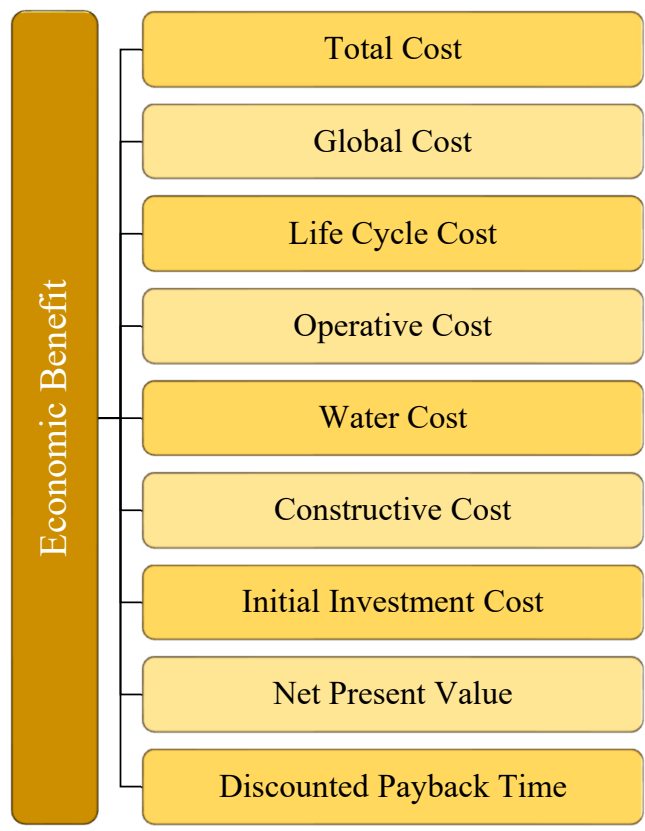

Figure 7. Economic indicators.

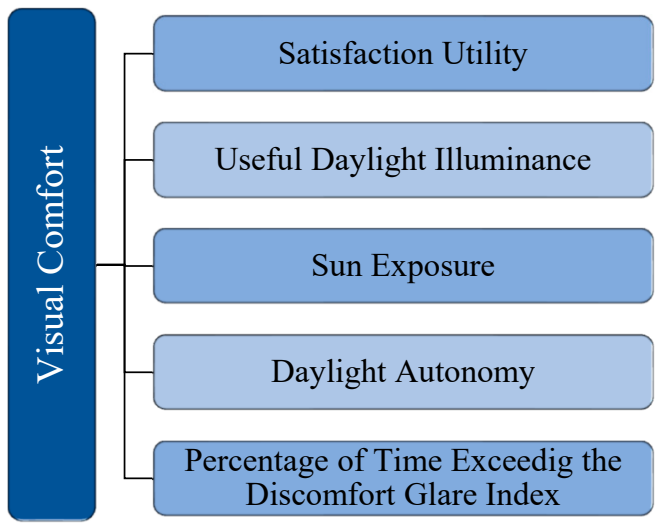

Figure 8. Visual comfort indicators.

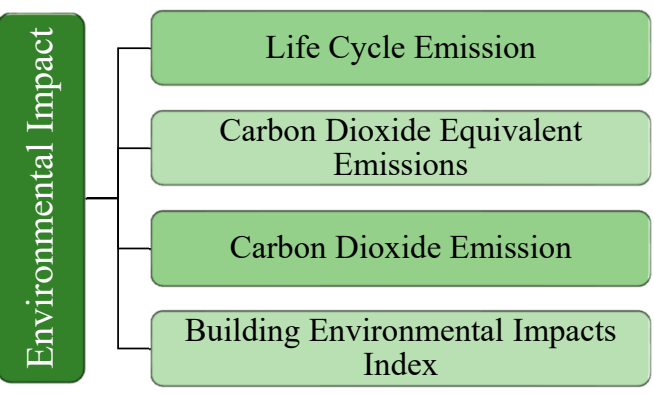

Figure 9. Environmental indicators.

\subsubsection{Others}

Here are the four other aspects that have been rarely studied in the reviewed investigations:

- Shape;

- Artwork preservation risk; 
- Aesthetic perception;

- Water consumption.

The indicators that have been used to optimize these aspects are introduced in Figure 10. Shape, artwork preservation risk, and aesthetic perception are well defined aspects in architecture; however, water consumption is popularly used in energy engineering. Zhang et al. [40] presented a three-objective optimization method to enhance the shape of a free-form building by maximizing solar radiation gain and shape efficiency and simultaneously minimizing the shape coefficient.

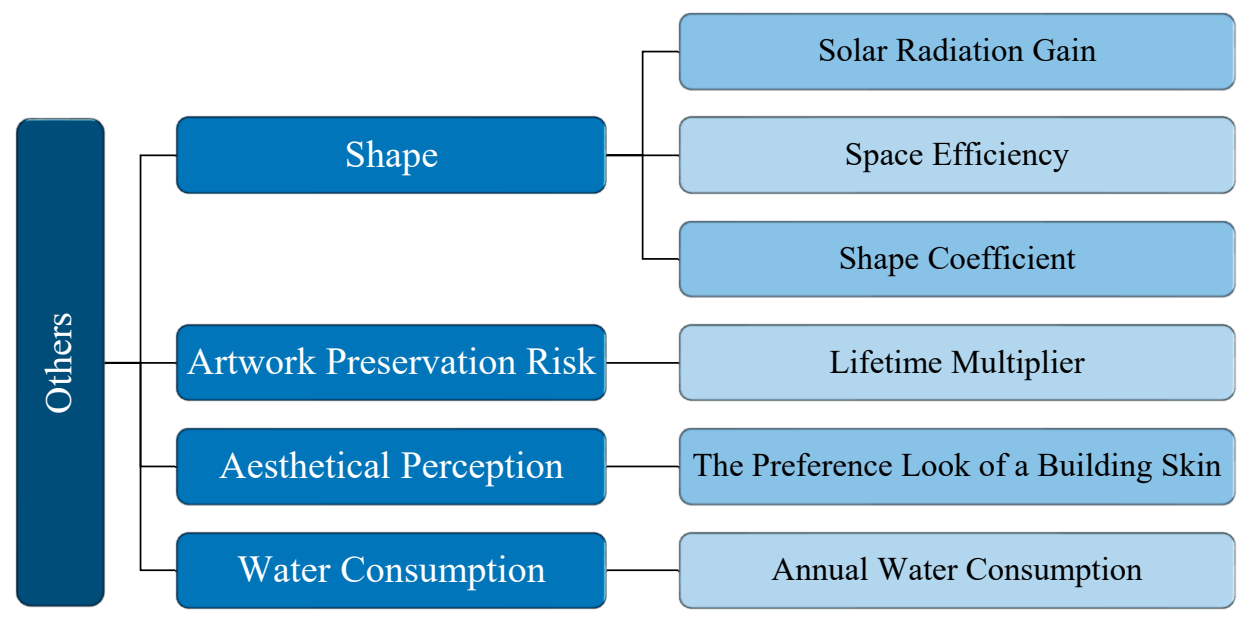

Figure 10. Other indicators.

Moreover, artwork perseveration risk is an important aspect that should be considered where the damage to sensitive objects is needed to be decreased [71]. Light, for example, can cause damage to artifacts, but it is critical for displaying them in museums; thus, an optimal solution should be presented [71]. In the study done by Schito et al. [52], artwork preservation risk was promoted by evaluating a lifetime multiplier to avoid artwork degradation; and an Italian museum was simulated as the case study where assessing artwork preservation risk is more effective.

Furthermore, reviewing a very recent study [57] that considered aesthetic perception as a qualitative aspect and changed it into a measurable goal has opened up a new perspective for future investigations. Additionally, Sohani et al. [72] optimized the water consumed during a year in a residential building.

\subsubsection{Summary Report}

Based on the review conducted, these different ranges of improvements have been achieved for each building aspect:

- $\quad$ E.C has been reduced in the range of $1.6 \%$ [67] to $60.1 \%$ [65] with an average of $26.13 \%$.

- T.C has been improved in the rage of $1.5 \%$ [37] to $60.0 \%$ [52] with an average of $25.61 \%$.

- E.B has been enhanced in the range of $4.6-39.56 \%$ [54] with an average of $24.0 \%$.

- V.C has been increased in the range of $15.0-63.0 \%$ [45] with an average of $35.0 \%$.

- The three indicators of the shape aspect, including solar radiation gain, shape coefficient, and space efficiency have been enhanced by $30-53 \%, 15-20 \%$, and less than $10 \%$ [40], respectively.

- A.P.R and W.C have been improved less than 10\% [52] and 153.2-390.0\% [65], respectively.

It should be underlined that these wide ranges were attributed to case study factors (function and location), optimization approaches, and key parameters considered (decision variables, objective function, and constraints), which are all investigated in different parts of this review. Moreover, since A.P is a qualitative aspect, it was not possible to report its enhancement in a numerical format. 


\subsection{Decision Variables}

In the simulation-based optimization, achieving the best solution is done by adjusting decision variables [73-75]. The decision variables are chosen among a group of parameters that affect the value of each objective function; they are called effective parameters [76]. In general, the decision variables reported in Table 4 are classified into two groups: architectural and mechanical. It should be noted that, in order to find the highest possible performance enhancement in the optimization, the decision variables from both groups should be taken into account.

\subsection{Constraints}

According to the limitations that come from technical or economic issues, some constraints are usually imposed on the optimization problem [77-79]. Constraints have been considered in $50 \%$ of the core literature. Technically, constraints are sorted out into two groups, equality and inequality [80-82]. Equality constraints are those that bind the optimization to satisfy the equations. In contrast, inequality constraints are not enforced to be at their limits [83-85]. Due to the computational difficulties caused by employing equality constraints, the constraints are usually considered in the form of inequality.

In some studies, several aspects that are mentioned in Section 4.1 have been taken into account as the constraints. As it was described before, this usually happens to reduce the number of objective functions and subsequently simplify the optimization process. For instance, Ascione et al. [60], Gadelhak and Lang [41], and Li et al. [33], have imposed thermal comfort, visual comfort, and energy consumption constraints, respectively. It should be underlined that the range of the decision variables (called as bound) has not been considered among the constraints, which are reported in Table 5.

\subsection{The Considered Case Studies}

In order to show the application of the proposed multi-objective optimization procedure, a case study has been usually considered in each investigation. The case study is a parameter which has substantial impacts on the values of objective functions and decision variables in the optimal condition, and it also might lead to adding or removing a number of objective functions, decision variables, and constraints.

Table 4. Decision variables which have been considered in the core literature.

\begin{tabular}{|c|c|}
\hline Study & Decision Variables \\
\hline Abdallah and El-Rayes [27] & $\begin{array}{l}\text { - } \quad \text { All energy and water consuming building equipment and fixtures } \\
\text { - } \quad \text { Energy-saving measures } \\
\text { - } \quad \text { Parameters related to solid waste management plans }\end{array}$ \\
\hline Mangkuto et al. [28] & $\begin{array}{l}\text { - Window to wall ratio } \\
\text { - Wall reflectance } \\
\text { - Window orientation }\end{array}$ \\
\hline Ferdyn-Grygierek and Grygierek [29] & $\begin{array}{ll}\text { - } & \text { Window type } \\
\text { - } & \text { Window area } \\
\text { - } & \text { Building orientation } \\
\text { - } & \text { Insulation of external wall, roof and ground floor } \\
& \text { Infion }\end{array}$ \\
\hline Baglivo et al. [30] & - Thermal characteristics affect the building load \\
\hline
\end{tabular}


Table 4. Cont.

\begin{tabular}{|c|c|}
\hline Study & Decision Variables \\
\hline Bamdad et al. [31] & $\begin{array}{ll}\text { - } & \text { Roof emissivity } \\
\text { - } & \text { Roof and wall solar absorptance } \\
\text { - } & \text { Window height } \\
\text { - } & \text { Overhang depth } \\
\text { - } & \text { Heating and cooling set-point } \\
\text { - } & \text { Building orientation }\end{array}$ \\
\hline Zhou et al. [32] & $\begin{array}{l}\text { - Window opening for ventilation } \\
\text { - Indoor air temperature }\end{array}$ \\
\hline Li et al. [33] & $\begin{array}{ll}\text { - } & \text { Story number } \\
\text { - } & \text { Dimensional characteristics } \\
\text { - } & \text { Window to wall ratio } \\
\text { - } & \text { Thermal characteristics of the building } \\
\text { - } & \text { Solar heat gain through the transparent areas }\end{array}$ \\
\hline Sghiouri et al. [34] & - Overhanging projection in rooms \\
\hline Xue et al. [35] & - Window to wall ratio \\
\hline Echenagucia et al. [36] & $\begin{array}{ll}\text { - } & \text { Wall thickness } \\
\text { - } & \text { Windows shape, placement and number } \\
\text { - } & \text { Glazing characteristics }\end{array}$ \\
\hline Yu et al. [37] & $\begin{array}{ll}\text { - } & \text { Floor area. } \\
\text { - } & \text { Building story } \\
\text { - } & \text { Orientation } \\
\text { - } & \text { Shape coefficient } \\
\text { - } & \text { Heat transfer coefficient of wall, roof and window } \\
\text { - } & \text { Thermal inertia index of wall and roof } \\
\text { - Window to wall ratio }\end{array}$ \\
\hline
\end{tabular}

Carlucci et al. [38]

- $\quad$ Glazing optical properties

- Windows orientation and extension

- $\quad$ Shading devices operation and typology

- Thermo-physical properties of external walls, roof, and floor

- Solar absorptance and infrared emittance of the external plastering

Ascione et al. [39]

- The thermal insulant thickness

- $\quad$ Brick thickness and density

- Windows thermal transmittance

Zhang et al. [40]

Gadelhak and Lang [41]
- $\quad$ The curve and the surface control-point coordinates. Each of them is made up of $\mathrm{X}, \mathrm{Y}$ and $\mathrm{Z}$ coordinates.
- Window to wall ratio

- Insulation thickness

- Glazing system

- $\quad$ Shading systems

- Daylight systems 
Table 4. Cont.

\begin{tabular}{|c|c|}
\hline Study & Decision Variables \\
\hline Pan et al. [42] & $\begin{array}{ll}\text { - } & \text { Building azimuth } \\
\text { - } & \text { Window to wall ratio } \\
\text { - } & \text { Heat transfer coefficient of window } \\
\text { - } & \text { Solar gain coefficient of window } \\
& \text { Insulation thickness }\end{array}$ \\
\hline Ascione et al. [43] & $\begin{array}{ll}\text { - } & \text { Roof and external walls solar absorptance } \\
\text { - } & \text { Roof and external walls insulation thickness } \\
\text { - } & \text { Window type } \\
\text { - } & \text { Shading system } \\
\text { - } & \text { Free cooling system } \\
\text { - } & \text { Boiler and chiller type } \\
\text { - } & \text { Photovoltaic roof coverage }\end{array}$ \\
\hline Bingham et al. [44] & $\begin{array}{l}\text { - } \quad \text { Construction of roof and exterior wall } \\
\text { - } \quad \text { Insulation type of exterior and interior wall and roof } \\
\text { - } \quad \text { Ilazing type } \\
\text { - } \quad \text { Lightiation thickness of wall and roof } \\
\text { - }\end{array}$ \\
\hline Zhang et al. [45] & $\begin{array}{ll}\text { - } & \text { Orientation } \\
\text { - } & \text { Room and corridor depth } \\
\text { - } & \text { Window to wall ratio } \\
\text { - } & \text { Glazing material } \\
\text { Shading type }\end{array}$ \\
\hline Mostavi et al. [46] & - Construction materials in different building components \\
\hline Bre and Fachinotti [47] & $\begin{array}{ll}\text { - } & \text { Building azimuth } \\
\text { - } & \text { Shading size } \\
\text { - } & \text { Infiltration rate } \\
\text { - } & \text { Area fraction of window for natural ventilation } \\
\text { - } & \text { Window width } \\
\text { - } & \text { Roof, wall, window and floor (the first floor) types }\end{array}$ \\
\hline Hamdy and Mauro [48] & $\begin{array}{l}\text { - Walls, roof and floor insulation } \\
\text { - } \quad \text { Window and shading type } \\
\text { - } \quad \text { Heat recovery, primary energy system and HVAC system type }\end{array}$ \\
\hline Wu et al. [49] & $\begin{array}{l}\text { - Wall material thickness } \\
\text { - } \quad \text { Window and outside door heat transfer coefficient } \\
\text { - } \quad \text { Area of photovoltaic }\end{array}$ \\
\hline Lin et al. [50] & $\begin{array}{ll}\text { - } & \text { Concrete thickness } \\
\text { - } & \text { Insulation thickness } \\
\text { - } & \text { Solar radiation absorptance } \\
\text { - } & \text { Window to wall ratio }\end{array}$ \\
\hline
\end{tabular}


Table 4. Cont.

\begin{tabular}{|c|c|}
\hline Study & Decision Variables \\
\hline Grygierek and Ferdyn-Grygierek [51] & $\begin{array}{ll}\text { - } & \text { Glazing type } \\
\text { - } & \text { Windows area } \\
\text { - } & \text { Building orientation } \\
\text { - } & \text { External wall, ground floor and roof insulation } \\
\text { - } & \text { Infiltration }\end{array}$ \\
\hline Schito et al. [52] & $\begin{array}{l}\text { - } \quad \text { Set-point values of temperature } \\
\text { - } \quad \text { Set-point values of relative humidity }\end{array}$ \\
\hline Gou et al. [53] & $\begin{array}{ll}\text { - } & \text { Building orientation } \\
\text { - } & \text { Window to wall ratio } \\
\text { - } & \text { Window U-value } \\
\text { - } & \text { Airtightow SHGC } \\
\text { - } & \text { Control type of window opening } \\
\text { - } & \text { External shading } \\
\text { - } & \text { Solar absorptance of building surface } \\
\text { - } & \text { Thickness of XPS board } \\
\text { - } & \text { Type of exterior wall }\end{array}$ \\
\hline
\end{tabular}

- Thickness of roof and external walls insulation

- Glazing type

Harkouss et al. [54] $\quad$ - Cooling/heating set point

- Solar collectors Number

- Photovoltaic array

- Windows width

\begin{tabular}{|c|c|}
\hline Sohani et al. [55] & - The specification of the HVAC system \\
\hline Zemero et al. [56] & $\begin{array}{ll}\text { - } & \text { Building shape } \\
\text { - } & \text { Materials of interior and exterior wall } \\
\text { - } & \text { Materials of roof and floor } \\
\text { - } & \text { Shadindow materials } \\
\text { - } & \text { Building orientation }\end{array}$ \\
\hline Yi [57] & $\begin{array}{l}\text { - Building skin's geometry elements: amplitude and period of the waves, } \\
\text { openings size }\end{array}$ \\
\hline Hong et al. [58] & $\begin{array}{ll}- & \text { Window type } \\
- & \text { Heating and cooling set-point } \\
\text { - } & \text { Type of ventilation and window opening }\end{array}$ \\
\hline Kirimtat et al. [59] & - $\quad$ Shading parameters \\
\hline Ascione et al. [60] & $\begin{array}{l}\text { - } \quad \text { Heating and cooling set-point } \\
\text { - } \quad \text { Roof and external walls solar absorptance } \\
\text { - } \quad \text { Insulation layer position } \\
\text { - } \quad \text { Thickness, thermal conductivity and density of the construction materials } \\
\text { - } \quad \text { Windows type } \\
\text { - Building orientation }\end{array}$ \\
\hline
\end{tabular}


Table 4. Cont

\begin{tabular}{|c|c|}
\hline Study & Decision Variables \\
\hline Zhai et al. [61] & $\begin{array}{ll}- & \text { WWR } \\
- & \text { Orientation } \\
- & \text { Glazing material }\end{array}$ \\
\hline Si et al. [62] & $\begin{array}{l}\text { - } \quad \text { Roofs and opaque walls thermal properties } \\
\text { - Window types } \\
\text { - } \quad \text { Eaves shape } \\
\text { Thermostat set-points }\end{array}$ \\
\hline Sharif and Hammad [63] & $\begin{array}{ll}\text { - } & \text { External walls, window frame, façade and roof types } \\
\text { - } & \text { Glazing template } \\
\text { - } & \text { HVAC } \text { and lighting systems } \\
\text { - } & \text { Operation schedules of heating and cooling } \\
\text { - } & \text { Open percentage of external window } \\
\text { - } & \text { Mechanical Ventilation Rate } \\
\text { - } & \text { Airtightness }\end{array}$ \\
\hline Fang and Cho [64] & $\begin{array}{ll}\text { - } & \text { Building depth } \\
\text { - } & \text { Location of roof ridge } \\
\text { - } & \text { Skylight width, length, location and orientation } \\
\text { - } & \text { Width of south and north window } \\
\text { - } & \text { Louver length }\end{array}$ \\
\hline Sohani et al. [65] & - The specification of the HVAC system \\
\hline Lu et al. [66] & $\begin{array}{ll}\text { - } & \text { Photovoltaic power generation capacity } \\
\text { - } & \text { Wind turbine power generation capacity } \\
\text { - } & \text { Bio-diesel generator capacity }\end{array}$ \\
\hline Delgarm et al. [67] & $\begin{array}{l}\text { - } \quad \text { Orientation. } \\
\text { - } \quad \text { Whading overhang characteristics } \\
\text { - } \quad \text { Glazing and wall material properties }\end{array}$ \\
\hline Delgarm et al. [68] & $\begin{array}{ll}\text { - } & \text { Orientation } \\
\text { - } & \text { Window size } \\
\text { - } & \text { Glazing and wall material properties }\end{array}$ \\
\hline Delgarm et al. [69] & $\begin{array}{ll}- & \text { Orientation } \\
\text { - } & \text { Window size } \\
\text { Characteristics of overhangs }\end{array}$ \\
\hline Xiong et al. [70] & - $\quad$ The shading position \\
\hline
\end{tabular}

In each optimization project, two factors about the case study have to be defined, including its function and location. As it is shown in Table 6, 13 different functions and a variety of locations have been taken into account in the core literature. These different functions and the number of papers in which each one has been studied are presented in Figure 11. 


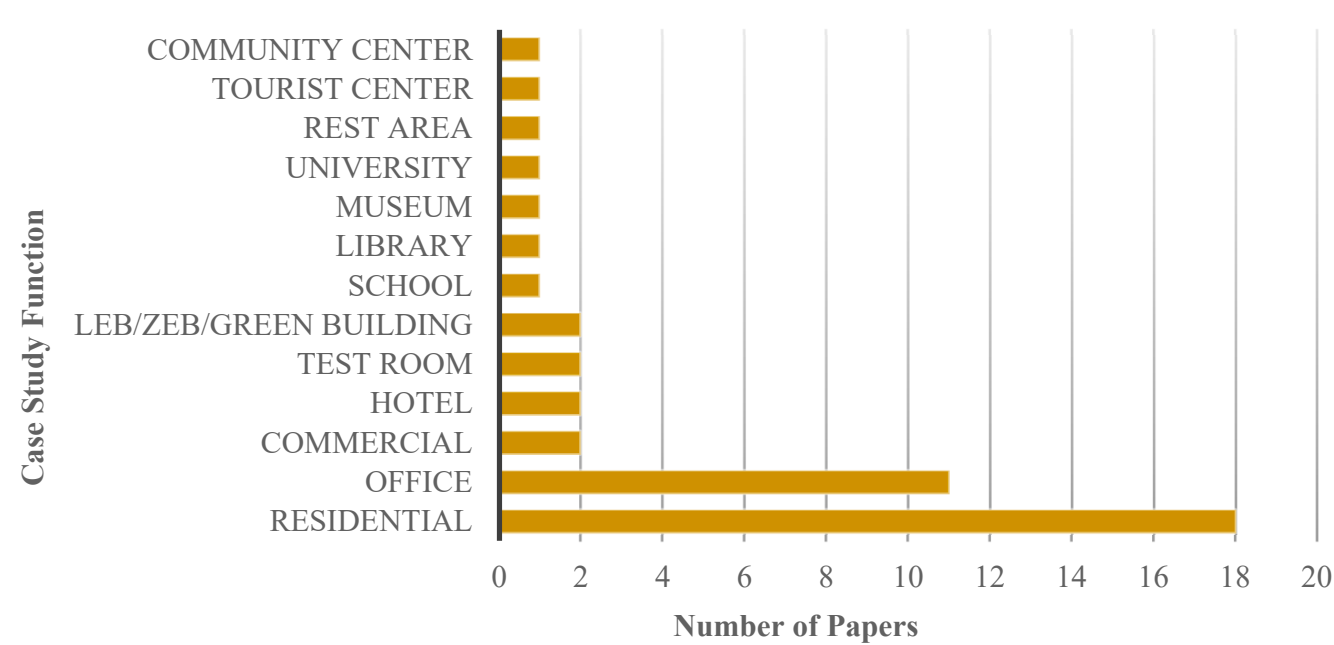

Figure 11. Different functions which have been considered as the case studies in the core literature in addition to the number of papers in which each one has been studied.

As two examples of the mentioned point about the impacts of the function and location of the case study on the selection of the objective functions, the investigations done by Schito et al. [52] and Zhang et al. [45] are considered, respectively. Schito et al. [52] chose a museum as the case study, which resulted in adding artwork preservation risk as one of the objective functions. In addition, considering the case study in Tianjin in China, Zhang et al. [45] eliminated the energy consumption for cooling because of its small portion of the total energy demand in the cold climate of China compared to the heating and lighting energy demands.

In order to provide more extensive insights, the graphical representation of the frequency of objective functions is given in the tree map format in Figure 12. The branches in this figure demonstrate a hierarchy view of the considered building functions in different colors. Moreover, the frequency of the building aspects in each of these functions is illustrated in the form of sub-branches.

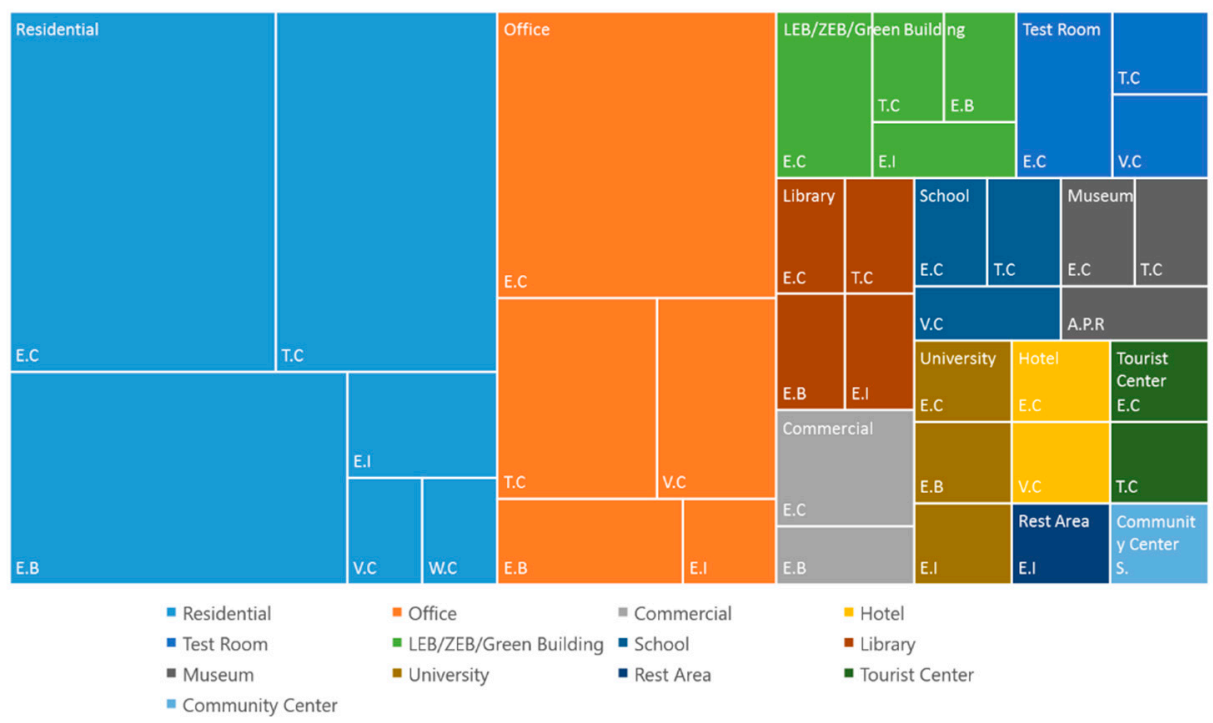

Figure 12. The frequency of the objective functions from different aspects for various applications in the tree map format. 
Table 5. Constraints which have been considered in the core literature.

\begin{tabular}{|c|c|}
\hline Study & Constraints \\
\hline Abdallah and El-Rayes [27] & - $\quad$ Budget \\
\hline Mangkuto et al. [28] & - Operational performance \\
\hline Ferdyn-Grygierek and Grygierek [29] & - Daylight metrics \\
\hline Baglivo et al. [30] & - Thermal comfort condition \\
\hline Bamdad et al. [31] & - \\
\hline Zhou et al. [32] & $\begin{array}{l}\text { N.N. } \\
\text { - Different eneroy efficiency standards. }\end{array}$ \\
\hline Li et al. [33] & - The energy consumption constraint \\
\hline Sghiouri et al. [34] & - N.A. \\
\hline Xue et al. [35] & - Davlighting performance \\
\hline Echenagucia et al. [36] & - N.A. \\
\hline Yu et al. [37] & N.A. \\
\hline Carlucci et al. [38] & - Minimum air change rate \\
\hline Ascione et al. [39] & - \\
\hline Zhang et al. [40] & - The functional requirements \\
\hline Gadelhak and Lang [41] & - Annual Sunlioht Exposure \\
\hline Pan et al. [42] & - N.A. \\
\hline Ascione et al. [43] & - $\quad$ The investment cost \\
\hline Bingham et al. [44] & - Percentage of Persons Dissatisfied \\
\hline Zhang et al. [45] & - N.M. \\
\hline Mostavi et al. [46] & N.M. \\
\hline Bre and Fachinotti [47] & N.IV. \\
\hline Hamdy and Mauro [48] & $\begin{array}{l}\text { N.A. } \\
\text { Overheating in summer }\end{array}$ \\
\hline Wu et al. [49] & - Heat transfer coefficient constraint \\
\hline Lin et al. [50] & - Heat transter coemincient constraint \\
\hline Grygierek and Ferdyn-Grygierek [51] & - Infiltration-related constraint \\
\hline Schito et al. [52] & • N.M. \\
\hline Gou et al. [53] & N.A. \\
\hline Harkouss et al. [54] & - The average predicted mean vote \\
\hline Sohani et al. [86] & - $\quad$ Supply air constraint \\
\hline Zemero et al. [56] & - $\quad$ Thermal comfort \\
\hline Yi [57] & - N.M. \\
\hline Hong et al. [58] & - Indoor environmental quality \\
\hline Kirimtat et al. [59] & - $\quad$ Budget \\
\hline Ascione et al. [60] & - The maximum number of discomfort \\
\hline Zhai et al. [61] & hours \\
\hline Si et al. [62] & N.A. \\
\hline Sharif and Hammad [63] & N.A. \\
\hline Fang and Cho [64] & $\begin{array}{ll}- & \text { N.A. } \\
\text { N.A. }\end{array}$ \\
\hline Sohani et al. [65] & $\begin{array}{l}\text { - } \quad \text { Supply air constraint } \\
\text { - } \quad \text { Geometrical limitation for channels' }\end{array}$ \\
\hline Lu et al. [66] & $\begin{array}{l}\text { height } \\
\text { Zero annual enerov balance }\end{array}$ \\
\hline Delgarm et al. [67] & - $\quad$ Lero annuar energy darance \\
\hline Delgarm et al. [68] & - N.A. \\
\hline Delgarm et al. [69] & N.A. \\
\hline Xiong et al. [70] & - $\quad$ Satisfaction utility (Only in SOO) \\
\hline
\end{tabular}


Table 6. Considered case studies in the core literature.

\begin{tabular}{|c|c|c|}
\hline Study & Building Function & Location \\
\hline Abdallah and El-Rayes [27] & Rest Area & N.M. \\
\hline Mangkuto et al. [28] & Office & Bandung in Indonesia \\
\hline Ferdyn-Grygierek and Grygierek [29] & Residential & Katowice in Poland \\
\hline Baglivo et al. [30] & Residential & Southern Italy \\
\hline Bamdad et al. [31] & Commercial & $\begin{array}{l}\text { Brisbane, Darwin, Hobart and Melbourne, } \\
\text { in Australia }\end{array}$ \\
\hline Zhou et al. [32] & Residential & Tianjin in China \\
\hline Li et al. [33] & Office & Beijing, Shanghai and Guangzhou, in China \\
\hline Sghiouri et al. [34] & Residential & Marrakech, Casablanca and Oujda, in Morocco \\
\hline Xue et al. [35] & Hotel & Shanghai, Qionghai and Fuzhou, in China \\
\hline Echenagucia et al. [36] & Office & Palermo, Torino, Frankfurt and Oslo \\
\hline Yu et al. [37] & Residential & Chongqing in China \\
\hline Carlucci et al. [38] & Residential & Mascalucia (CT) in Southern Italy \\
\hline Ascione et al. [39] & Residential & Naples in Italy and Istanbul in Turkey \\
\hline Zhang et al. [40] & Community Center & Shenyang in China \\
\hline Gadelhak and Lang [41] & Office & Cairo in Egypt and Munich in Germany \\
\hline Pan et al. [42] & Residential & Nanjing in China \\
\hline Ascione et al. [43] & Office & Naples in South Italy \\
\hline Bingham et al. [44] & Residential & Bahamas \\
\hline Zhang et al. [45] & School & Tianjin in China \\
\hline Mostavi et al. [46] & Office & Pennsylvania in The USA \\
\hline Bre and Fachinotti [47] & Residential & Paraná in Argentine \\
\hline Hamdy and Mauro [48] & Residential & Helsinki in Finland \\
\hline Wu et al. [49] & Residential & Tianjin in China \\
\hline Lin et al. [50] & A two-star green building & Wuhan in China. \\
\hline Grygierek and Ferdyn-Grygierek [51] & Residential & Poland \\
\hline Schito et al. [52] & Museum & Pisa in Italy \\
\hline Gou et al. [53] & Residential & Shanghai in China \\
\hline Harkouss et al. [54] & Residential & $\begin{array}{c}\text { Beirut, Qartaba, Zahle and Cedars in Lebanon, } \\
\text { Embrun, La Rochelle, Nice, Nancy and Limoges } \\
\text { in France }\end{array}$ \\
\hline Sohani et al. [86] & Residential & $\begin{array}{l}\text { Riyadh in Saudi Arabia, Ahmedabad in India, } \\
\text { Windsor in Canada, London in the UK }\end{array}$ \\
\hline Zemero et al. [56] & Commercial & $\begin{array}{l}\text { Curitiba, Florianópolis, Campo Grande and } \\
\text { Belém in Brazil }\end{array}$ \\
\hline Yi [57] & Hotel & Barcelona in Spain \\
\hline Hong et al. [58] & Library & Seoul in South Korea \\
\hline Kirimtat et al. [59] & Office & Izmir in Turkey \\
\hline Ascione et al. [60] & Residential & $\begin{array}{c}\text { Palermo, Naples, Milan and Florence, } \\
\text { In Italy }\end{array}$ \\
\hline Zhai et al. [61] & Test room & Xi'an in China \\
\hline
\end{tabular}


Table 6. Cont.

\begin{tabular}{|c|c|c|}
\hline Study & Building Function & Location \\
\hline Si et al. [62] & Tourist center & Nanjing in China \\
\hline Sharif and Hammad [63] & University & Montreal in Canada \\
\hline Fang and Cho [64] & Office & Miami, Atlanta, Chicago in the USA \\
\hline Sohani et al. [65] & Residential & $\begin{array}{l}\text { Riyadh in Saudi Arabia, Ahmedabad in India, } \\
\text { Windsor in Canada, London in the UK }\end{array}$ \\
\hline Lu et al. [66] & $\begin{array}{l}\text { Two types of buildings (LEB and } \\
\text { ZEB) }\end{array}$ & Hong Kong in China \\
\hline Delgarm et al. [67] & $\begin{array}{l}\text { A single thermal zone test case } \\
\text { room. }\end{array}$ & $\begin{array}{l}\text { Tabriz, Tehran, Kerman and Bandar } \\
\text { Abbas, in Iran }\end{array}$ \\
\hline Delgarm et al. [68] & Office & $\begin{array}{l}\text { Tabriz, Tehran, Kerman and Bandar } \\
\text { Abbas, in Iran }\end{array}$ \\
\hline Delgarm et al. [69] & Office & $\begin{array}{l}\text { Tabriz, Tehran, Kerman and Bandar } \\
\text { Abbas, in Iran }\end{array}$ \\
\hline Xiong et al. [70] & Office & West Lafayette in Indiana \\
\hline
\end{tabular}

\subsection{Optimization Algorithm and Simulation Software}

Based on the type of optimization approach, i.e., either $\mathrm{SOO}$ or $\mathrm{MOO}$, different algorithms have been used to acquire the optimum solution. The optimization algorithm and the software which have been used in each study are shown in Table 7. For SOO, the genetic algorithm is the most dominant method, whereas the non-dominated sorting genetic algorithm II (NSGA-II) has been the mostly-used in the MOO. Both SOO and MOO have been usually done using MATLAB.

Table 7. The optimization algorithms and the software which have been used in the core literature.

\begin{tabular}{|c|c|c|c|}
\hline \multirow{2}{*}{ Study } & \multirow{2}{*}{ Optimization Algorithm } & \multicolumn{2}{|c|}{ Software } \\
\hline & & Simulation & Optimization \\
\hline Abdallah and El-Rayes [27] & Genetic Algorithm & eQUEST & N.M. \\
\hline Mangkuto et al. [28] & $\begin{array}{c}\text { Graphical Optimisation } \\
\text { Method }\end{array}$ & Radiance, Daysim & N.M. \\
\hline $\begin{array}{l}\text { Ferdyn-Grygierek and } \\
\text { Grygierek [29] }\end{array}$ & Genetic Algorithm & EnergyPlus & MATLAB \\
\hline Baglivo et al. [30] & Sequential Search Technique & TRNSYS & TRNSYS \\
\hline Bamdad et al. [31] & $\begin{array}{l}\text { Ant Colony Optimisation for } \\
\text { continuous domain }\end{array}$ & EnergyPlus & GenOpt, MATALB \\
\hline Zhou et al. [32] & Measurement & N.A. & N.A. \\
\hline Li et al. [33] & Genetic Algorithm & DesignBuilder, Radiance & MATLAB \\
\hline Sghiouri et al. [34] & NSGA-II & TRNSYS & jEPlus + EA \\
\hline Xue et al. [35] & N.M. & Radiance, EnergyPlus & N.M. \\
\hline Echenagucia et al. [36] & NSGA-II & EnergyPlus & Python \\
\hline Yu et al. [37] & NSGA-II & EnergyPlus & MATLAB \\
\hline Carlucci et al. [38] & NSGA-II & EnergyPlus & $\begin{array}{l}\text { GenOpt, Java Genetic } \\
\text { Algorithms Package }\end{array}$ \\
\hline Ascione et al. [39] & NSGA-II & EnergyPlus & MATLAB \\
\hline Zhang et al. [40] & $\begin{array}{c}\text { Multi-objective Genetic } \\
\text { Algorithm }\end{array}$ & $\begin{array}{l}\text { Rhinoceros and its plug-ins } \\
\text { Grasshopper, Ladybug, }\end{array}$ & Octopus \\
\hline
\end{tabular}


Table 7. Cont.

\begin{tabular}{|c|c|c|c|}
\hline \multirow{2}{*}{ Study } & \multirow{2}{*}{ Optimization Algorithm } & \multicolumn{2}{|c|}{ Software } \\
\hline & & Simulation & Optimization \\
\hline Gadelhak and Lang [41] & $\begin{array}{l}\text { Multi-Objective SPEA-2 } \\
\text { Optimization Algorithm }\end{array}$ & $\begin{array}{c}\text { Rhinoceros's plug-ins Diva, } \\
\text { Grasshopper, Ladybug and } \\
\text { Honeybee }\end{array}$ & Octopus \\
\hline Pan et al. [42] & NSGA-II & EnergyPlus & MATLAB \\
\hline Ascione et al. [43] & $\begin{array}{c}\text { Multi-objective Genetic } \\
\text { Algorithm }\end{array}$ & EnergyPlus & MATLAB \\
\hline Bingham et al. [44] & NSGA-II & EnergyPlus & jEPlus + EA \\
\hline Zhang et al. [45] & $\begin{array}{l}\text { Multi-Objective SPEA-2 } \\
\text { Optimization Algorithm }\end{array}$ & $\begin{array}{c}\text { Rhinoceros and its plug-ins } \\
\text { Grasshopper, Ladybug, } \\
\text { Honeybee }\end{array}$ & Octopus \\
\hline Mostavi et al. [46] & $\begin{array}{l}\text { A Harmony Search Based } \\
\text { Algorithm }\end{array}$ & EnergyPlus & C\# \\
\hline Bre and Fachinotti [47] & NSGA-II & EnergyPlus & Python \\
\hline Hamdy and Mauro [48] & $\begin{array}{c}\text { The optimization algorithm } \\
\text { PR_GA_RF }\end{array}$ & IDA ICE & MATLAB \\
\hline Wu et al. [49] & NSGA-II & DesignBuilder & MATLAB \\
\hline Lin et al. [50] & $\begin{array}{l}\text { Multi-objective Genetic } \\
\text { Algorithm }\end{array}$ & DesignBuilder & MATLAB \\
\hline $\begin{array}{c}\text { Grygierek and } \\
\text { Ferdyn-Grygierek [51] }\end{array}$ & NSGA-II & EnergyPlus & MATLAB \\
\hline Schito et al. [52] & N.M. & TRNSYS & MATLAB \\
\hline Gou et al. [53] & $\begin{array}{l}\text { NSGA-II coupled with the } \\
\text { Artificial Neural Network }\end{array}$ & EnergyPlus & $\begin{array}{l}\text { MATLAB, } \\
\text { jE-Plus }\end{array}$ \\
\hline Harkouss et al. [54] & NSGA-II & TRNSYS & MOBO \\
\hline Sohani et al. [86] & NSGA-II & $\begin{array}{c}\text { Carrier Hourly Analysis } \\
\text { Program }\end{array}$ & MATLAB \\
\hline Zemero et al. [56] & $\begin{array}{l}\text { PAES multi-objective } \\
\text { optimization algorithm }\end{array}$ & EnergyPlus & Python \\
\hline Yi [57] & NSGA-II & $\begin{array}{c}\text { Rhinoceros and its plug-ins } \\
\text { DIVA, Grasshopper and } \\
\text { Human UI }\end{array}$ & MATLAB \\
\hline Hong et al. [58] & NSGA-II & EnergyPlus & Python \\
\hline Kirimtat et al. [59] & $\begin{array}{l}\text { Non-dominated Sorting } \\
\text { Genetic Algorithm and } \\
\text { Self-adaptive Continuous } \\
\text { Genetic Algorithm with } \\
\text { Differential Evolution }\end{array}$ & Radiance, EnergyPlus & N.M. \\
\hline Ascione et al. [60] & NSGA-II & EnergyPlus & MATLAB \\
\hline Zhai et al. [61] & NSGA-II & EnergyPlus & MATLAB \\
\hline Si et al. [62] & NSGA-II & EnergyPlus & MATLAB, modeFrontier \\
\hline Sharif and Hammad [63] & NSGA-II & DesignBuilder & ATHENA \\
\hline Fang and Cho [64] & $\begin{array}{l}\text { Multi-objective Genetic } \\
\text { Algorithm }\end{array}$ & $\begin{array}{c}\text { Rhinoceros and its plug-ins } \\
\text { Grasshopper, Ladybug, } \\
\text { Honeybee }\end{array}$ & Octopus \\
\hline
\end{tabular}


Table 7. Cont.

\begin{tabular}{cccc}
\hline \multirow{2}{*}{ Study } & Optimization Algorithm & Simulation & Software \\
\cline { 3 - 4 } Sohani et al. [65] & NSGA-II & $\begin{array}{c}\text { Carrier Hourly Analysis } \\
\text { Program }\end{array}$ & MATLAB \\
\hline Lu et al. [66] & NSGA-II & TRNSYS & MATLAB \\
\hline Delgarm et al. [67] & $\begin{array}{c}\text { Multi-Objective Particle } \\
\text { Swarm Optimization } \\
\text { Algorithm }\end{array}$ & EnergyPlus & MATLAB \\
\hline Delgarm et al. [68] & $\begin{array}{c}\text { Multi-Objective Artificial Bee } \\
\text { Colony Optimization } \\
\text { Algorithm }\end{array}$ & EnergyPlus & MATLAB \\
\hline Delgarm et al. [69] & NSGA-II & EnergyPlus & MATLAB, \\
jE-Plus
\end{tabular}

For the simulation of the building, EnergyPlus has been the favorite software in the reviewed investigations. EnergyPlus and OpenStudio, which is used as its graphical user interface, are both open-source software programs, and that is a big advantage of them. Moreover, EnergyPlus has the potential of being easily coupled with MATLAB. In addition to EnergyPlus, Rhino has been increasingly used in recent studies. In fact, its user-friendly environment accounted for its popularity among researchers, although it is not open-source. Furthermore, among all the software programs that have been used in the literature, eQuest, Radiance, and some of Rhino's plugins, including Ladybug and Honeybee, are free to use. Software programs in the future could be promoted by taking the following items into account to become more helpful:

- Using artificial intelligence tools to provide predictions from changes in occupants' behavior and climate change in the future years of building life.

- Adding more powerful economic databases for better evaluation of the building from this point of view.

- Providing "tagging" possibility for each project done by an individual in a way that if wanted, could enable the tags to be shared on an online database with other people. In this way, researchers will have better interactions together.

- Applying the virtual reality to get the chance of understanding the graphical issues related to works in a much more perfect way.

\section{Conclusions}

In order to provide a new perspective into the literature, the studies that have been conducted to optimize the building performance were reviewed from different viewpoints. The core literature consists of 44 recent studies that were investigated in detail and all the key parameters involved in the optimization procedure were described individually. The review showed that there is a strong connection among these parameters. Moreover, selection of such parameters in the optimization should be done based on the function and location of the case study, and the requirements of the experts who are involved in the project practically. In addition, it is found that EnergyPlus and MATLAB have been the most-used software programs for building simulation and optimization, respectively. Among the nine various aspects that have been considered in the reviewed studies, energy consumption has been taken into account as the objective function more than others, accounting for $38.6 \%$. Thermal comfort and economic benefits with shares of $22.7 \%$ and $17 \%$ are the second and third mostly optimized aspects, respectively. Figure 13 demonstrates a graphical view of the conclusion. 


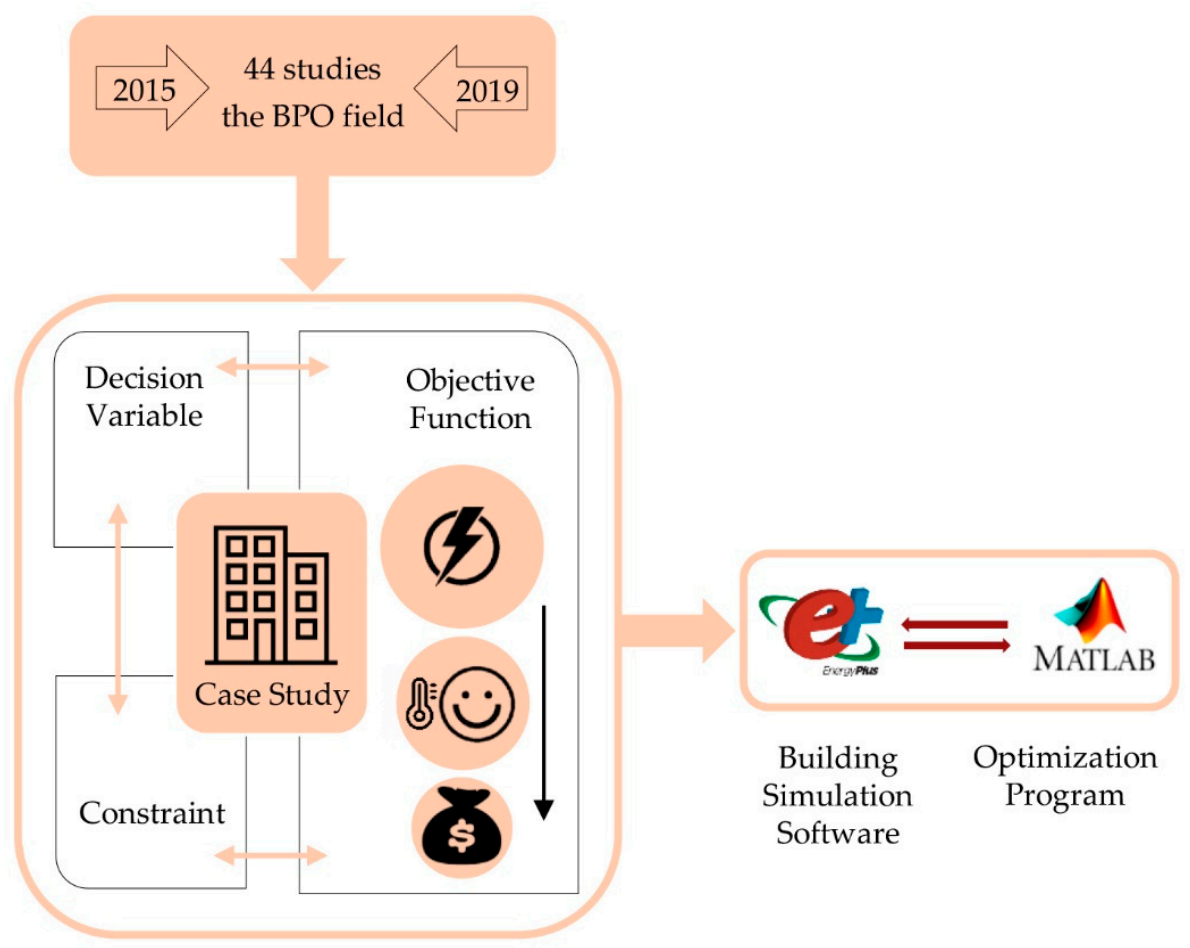

Figure 13. The graphical description of the work.

In addition, based on the conducted review, a number of open questions could be identified, which are:

- How could the policy makers help to put the results of BPO into practice for a town, a city, or a country?

- How could changing the occupants' behavior could affect the optimum values of decision variables and objective functions?

- Could some dimensionless numbers be defined as the decision variables and objective functions to reach a general BPO method and provide the possibility of better comparisons for various buildings?

- Would it be possible to find an updated procedure for BPO in which different buildings are optimized altogether? How much further improvement will be achieved under that condition?

- $\quad$ Could the current BPO procedure be modified to provide plans for adding renewable energy resources?

- How many changes will be made to the results of BPO by the future changes in the climate, buildings design techniques, and the employed masonry materials?

Moreover, as observed, in a large number of the studies, objective functions, decision variables, and constraints have not been selected comprehensively. For instance, the researchers who have a background in architecture have not considered the objective functions, decision variables, or constraints from energy or mechanical sides and vice versa. The reported information of this review will help the future researchers to avoid such issues.

Furthermore, the following items can be suggested based on the conducted literature review for future investigations:

- Conducting multi-objective optimization in which more aspects from different sides are taken into account;

- Performing multi-objective optimization by considering the objective functions based on the application and the climatic zone;

- Combining the efficient software programs and algorithms to have more effective and faster calculations; 
- Selecting the case studies in which the multi-objective optimization has been done less often, and taking the advantage of BPO for them;

- Identifying the aspects which have not been usually optimized in each application and considering them;

- Studying the impacts of different strategies for giving incentives to implement the results of BPO;

- Taking advantage of new optimization techniques like dynamic multi-objective optimization to provide a better outcome.

Funding: This research received no external funding.

Conflicts of Interest: The authors declare no conflict of interest.

\begin{tabular}{ll}
\multicolumn{2}{l}{ Abbreviations } \\
SOO & single-objective optimization \\
MOO & multi-objective optimization \\
BPO & building performance optimization \\
E.C & energy consumption \\
T.C & thermal comfort \\
E.B & economic benefit \\
V.C & visual comfort \\
E.I & environmental impact \\
S. & shape \\
A.P.R & artwork preservation risk \\
A.P & aesthetical perception \\
W.C & water consumption \\
NSGA-II & non-dominated sorting genetic algorithm II
\end{tabular}

\section{References}

1. Manfren, M.; Nastasi, B.; Tronchin, L. Linking design and operation phase energy performance analysis through regression-based approaches. Front. Energy Res. 2020, 8, 557649. [CrossRef]

2. Mancini, F.; Nardecchia, F.; Groppi, D.; Ruperto, F.; Romeo, C. Indoor Environmental Quality Analysis for Optimizing Energy Consumptions Varying Air Ventilation Rates. Sustainability 2020, 12, 482. [CrossRef]

3. Hoseinzadeh, S.; Hadi Zakeri, M.; Shirkhani, A.; Chamkha, A.J. Analysis of energy consumption improvements of a zero-energy building in a humid mountainous area. J. Renew. Sustain. Energy 2019, 11, 015103. [CrossRef]

4. Safari, M.; Sohani, A.; Sayyaadi, H. A higher performance optimum design for a tri-generation system by taking the advantage of water-energy nexus. J. Clean. Prod. 2021, 284, 124704. [CrossRef]

5. Adhikari, R.S.; Aste, N.; Manfren, M. Optimization concepts in district energy design and management-A case study. Energy Procedia 2012, 14, 1386-1391. [CrossRef]

6. Astiaso Garcia, D.; Cumo, F.; Tiberi, M.; Sforzini, V.; Piras, G. Cost-benefit analysis for energy management in public buildings: Four Italian case studies. Energies 2016, 9, 522. [CrossRef]

7. Dagdougui, Y.; Ouammi, A.; Benchrifa, R. High Level Controller based Energy Management for a Smart Building Integrated Microgrid with Electric Vehicle. Front. Energy Res. 2020, 8, 248. [CrossRef]

8. Sohani, A.; Sayyaadi, H. Employing genetic programming to find the best correlation to predict temperature of solar photovoltaic panels. Energy Convers. Manag. 2020, 224, 113291. [CrossRef]

9. Tronchin, L.; Manfren, M.; Tagliabue, L.C. Optimization of building energy performance by means of multi-scale analysis-Lessons learned from case studies. Sustain. Cities Soc. 2016, 27, 296-306. [CrossRef]

10. Elnagar, E.; Köhler, B. Reduction of the energy demand with passive approaches in multifamily nearly Zero-Energy Buildings under different climate conditions. Front. Energy Res. 2020, 8, 224. [CrossRef]

11. Sarafraz, M.M.; Dareh Baghi, A.; Safaei, M.R.; Leon, A.S.; Ghomashchi, R.; Goodarzi, M.; Lin, C.-X. Assessment of Iron Oxide (III)-Therminol 66 Nanofluid as a Novel Working Fluid in a Convective Radiator Heating System for Buildings. Energies 2019, 12, 4327. [CrossRef]

12. Fajilla, G.; De Simone, M.; Cabeza, L.F.; Bragança, L. Assessment of the Impact of Occupants' Behavior and Climate Change on Heating and Cooling Energy Needs of Buildings. Energies 2020, 13, 6468. [CrossRef]

13. Grygierek, K.; Sarna, I. Impact of Passive Cooling on Thermal Comfort in a Single-Family Building for Current and Future Climate Conditions. Energies 2020, 13, 5332. [CrossRef] 
14. Pacak, A.; Worek, W. Review of Dew Point Evaporative Cooling Technology for Air Conditioning Applications. Appl. Sci. 2021, 11, 934. [CrossRef]

15. Sayegh, M.A.; Ludwińska, A.; Rajski, K.; Dudkiewicz, E. Environmental and energy saving potential from greywater in hotels. Sci. Total Environ. 2021, 761, 143220. [CrossRef]

16. Golizadeh Akhlaghi, Y.; Aslansefat, K.; Zhao, X.; Sadati, S.; Badiei, A.; Xiao, X.; Shittu, S.; Fan, Y.; Ma, X. Hourly performance forecast of a dew point cooler using explainable Artificial Intelligence and evolutionary optimisations by 2050. Appl. Energy 2021, 281, 116062. [CrossRef]

17. Settino, J.; Carpino, C.; Perrella, S.; Arcuri, N. Multi-Objective Analysis of a Fixed Solar Shading System in Different Climatic Areas. Energies 2020, 13, 3249. [CrossRef]

18. Wong, J.K.W.; Zhou, J. Enhancing environmental sustainability over building life cycles through green BIM: A review. Autom. Constr. 2015, 57, 156-165. [CrossRef]

19. Carlucci, S.; Causone, F.; De Rosa, F.; Pagliano, L. A review of indices for assessing visual comfort with a view to their use in optimization processes to support building integrated design. Renew. Sustain. Energy Rev. 2015, 47, 1016-1033. [CrossRef]

20. Shi, X.; Tian, Z.; Chen, W.; Si, B.; Jin, X. A review on building energy efficient design optimization rom the perspective of architects. Renew. Sustain. Energy Rev. 2016, 65, 872-884. [CrossRef]

21. Bonyadi, M.R.; Michalewicz, Z. Particle Swarm Optimization for Single Objective Continuous Space Problems: A Review; MIT Press: Cambridge, MA, USA, 2017.

22. Kumar, A.; Sah, B.; Singh, A.R.; Deng, Y.; He, X.; Kumar, P.; Bansal, R. A review of multi criteria decision making (MCDM) towards sustainable renewable energy development. Renew. Sustain. Energy Rev. 2017, 69, 596-609. [CrossRef]

23. Tian, Z.; Zhang, X.; Jin, X.; Zhou, X.; Si, B.; Shi, X. Towards adoption of building energy simulation and optimization for passive building design: A survey and a review. Energy Build. 2018, 158, 1306-1316. [CrossRef]

24. Ekici, B.; Cubukcuoglu, C.; Turrin, M.; Sariyildiz, I.S. Performative computational architecture using swarm and evolutionary optimisation: A review. Build. Environ. 2019, 147, 356-371. [CrossRef]

25. Alothaimeen, I.; Arditi, D. Overview of multi-objective optimization approaches in construction project management. In Multi-criteria Optimization-Pareto-Optimal and Related Principles; IntechOpen: London, UK, 2019.

26. Joench, R.L.; Soares, J.; Lezama, F.; Ramos, S.; Gomes, A.; Vale, Z. A Short Review on Smart Building Energy Resource Optimization. In Proceedings of the 2019 IEEE PES GTD Grand International Conference and Exposition Asia (GTD Asia), Bangkok, Thailand, 19-23 March 2019; pp. 440-445.

27. Abdallah, M.; El-Rayes, K. Optimizing the selection of building upgrade measures to minimize the operational negative environmental impacts of existing buildings. Build. Environ. 2015, 84, 32-43. [CrossRef]

28. Mangkuto, R.A.; Rohmah, M.; Asri, A.D. Design optimisation for window size, orientation, and wall reflectance with regard to various daylight metrics and lighting energy demand: A case study of buildings in the tropics. Appl. Energy 2016, 164, 211-219. [CrossRef]

29. Ferdyn-Grygierek, J.; Grygierek, K. Multi-variable optimization of building thermal design using genetic algorithms. Energies 2017, 10, 1570. [CrossRef]

30. Baglivo, C.; Congedo, P.; Di Cataldo, M.; Coluccia, L.; D’Agostino, D. Envelope design optimization by thermal modelling of a building in a warm climate. Energies 2017, 10, 1808. [CrossRef]

31. Bamdad, K.; Cholette, M.E.; Guan, L.; Bell, J. Ant colony algorithm for building energy optimisation problems and comparison with benchmark algorithms. Energy Build. 2017, 154, 404-414. [CrossRef]

32. Zhou, Z.; Wang, C.; Sun, X.; Gao, F.; Feng, W.; Zillante, G. Heating energy saving potential from building envelope design and operation optimization in residential buildings: A case study in northern China. J. Clean. Prod. 2018, 174, 413-423. [CrossRef]

33. Li, Z.; Chen, H.; Lin, B.; Zhu, Y. Fast bidirectional building performance optimization at the early design stage. Build. Simul. 2018, 11, 647-661. [CrossRef]

34. Sghiouri, H.; Mezrhab, A.; Karkri, M.; Naji, H. Shading devices optimization to enhance thermal comfort and energy performance of a residential building in Morocco. J. Build. Eng. 2018, 18, 292-302. [CrossRef]

35. Xue, P.; Li, Q.; Xie, J.; Zhao, M.; Liu, J. Optimization of window-to-wall ratio with sunshades in China low latitude region considering daylighting and energy saving requirements. Appl. Energy 2019, 233, 62-70. [CrossRef]

36. Echenagucia, T.M.; Capozzoli, A.; Cascone, Y.; Sassone, M. The early design stage of a building envelope: Multi-objective search through heating, cooling and lighting energy performance analysis. Appl. Energy 2015, 154, 577-591. [CrossRef]

37. Yu, W.; Li, B.; Jia, H.; Zhang, M.; Wang, D. Application of multi-objective genetic algorithm to optimize energy efficiency and thermal comfort in building design. Energy Build. 2015, 88, 135-143. [CrossRef]

38. Carlucci, S.; Cattarin, G.; Causone, F.; Pagliano, L. Multi-objective optimization of a nearly zero-energy building based on thermal and visual discomfort minimization using a non-dominated sorting genetic algorithm (NSGA-II). Energy Build. 2015, 104, 378-394. [CrossRef]

39. Ascione, F.; Bianco, N.; De Masi, R.; Mauro, G.; Vanoli, G. Design of the building envelope: A novel multi-objective approach for the optimization of energy performance and thermal comfort. Sustainability 2015, 7, 10809-10836. [CrossRef]

40. Zhang, L.; Zhang, L.; Wang, Y. Shape optimization of free-form buildings based on solar radiation gain and space efficiency using a multi-objective genetic algorithm in the severe cold zones of China. Sol. Energy 2016, 132, 38-50. [CrossRef] 
41. Gadelhak, M.; Lang, W. Optimization of office building facade to enhance daylighting, thermal comfort and energy use intensity. In Proceedings of the Third IBPSA-England Conference, Newcastle Upon Tyne, UK, 12-14 September 2016; pp. 12-14.

42. Pan, L.; Li, K.; Xue, W.; Liu, G. Multi-objective optimization for building performance design considering thermal comfort and energy consumption. In Proceedings of the 2016 35th Chinese Control Conference (CCC), Chengdu, China, 27-29 July 2016; pp. 2799-2803.

43. Ascione, F.; Bianco, N.; De Stasio, C.; Mauro, G.M.; Vanoli, G.P. CASA, cost-optimal analysis by multi-objective optimisation and artificial neural networks: A new framework for the robust assessment of cost-optimal energy retrofit, feasible for any building. Energy Build. 2017, 146, 200-219. [CrossRef]

44. Bingham, R.; Agelin-Chaab, M.; Rosen, M.A. Multi-objective optimization of a residential building envelope in the bahamas. In Proceedings of the 2017 IEEE International Conference on Smart Energy Grid Engineering (SEGE), Oshawa, ON, Canada, 14-17 August 2017; pp. 294-301.

45. Zhang, A.; Bokel, R.; van den Dobbelsteen, A.; Sun, Y.; Huang, Q.; Zhang, Q. Optimization of thermal and daylight performance of school buildings based on a multi-objective genetic algorithm in the cold climate of China. Energy Build. 2017, 139, 371-384 [CrossRef]

46. Mostavi, E.; Asadi, S.; Boussaa, D. Development of a new methodology to optimize building life cycle cost, environmental impacts, and occupant satisfaction. Energy 2017, 121, 606-615. [CrossRef]

47. Bre, F.; Fachinotti, V.D. A computational multi-objective optimization method to improve energy efficiency and thermal comfort in dwellings. Energy Build. 2017, 154, 283-294. [CrossRef]

48. Hamdy, M.; Mauro, G. Multi-Objective Optimization of Building Energy Design to Reconcile Collective and Private Perspectives: CO2-eq vs. Discounted Payback Time. Energies 2017, 10, 1016. [CrossRef]

49. Wu, W.; Guo, J.; Li, J.; Hou, H.; Meng, Q.; Wang, W. A multi-objective optimization design method in zero energy building study: A case study concerning small mass buildings in cold district of China. Energy Build. 2018, 158, 1613-1624. [CrossRef]

50. Lin, Y.; Zhou, S.; Yang, W.; Li, C.-Q. Design optimization considering variable thermal mass, insulation, absorptance of solar radiation, and glazing ratio using a prediction model and genetic algorithm. Sustainability 2018, 10, 336. [CrossRef]

51. Grygierek, K.; Ferdyn-Grygierek, J. Multi-objective optimization of the envelope of building with natural ventilation. Energies 2018, 11, 1383. [CrossRef]

52. Schito, E.; Conti, P.; Testi, D. Multi-objective optimization of microclimate in museums for concurrent reduction of energy needs, visitors' discomfort and artwork preservation risks. Appl. Energy 2018, 224, 147-159. [CrossRef]

53. Gou, S.; Nik, V.M.; Scartezzini, J.-L.; Zhao, Q.; Li, Z. Passive design optimization of newly-built residential buildings in Shanghai for improving indoor thermal comfort while reducing building energy demand. Energy Build. 2018, 169, 484-506. [CrossRef]

54. Harkouss, F.; Fardoun, F.; Biwole, P.H. Multi-objective optimization methodology for net zero energy buildings. J. Build. Eng. 2018, 16, 57-71. [CrossRef]

55. Sohani, A.; Sayyaadi, H.; Zeraatpisheh, M. Optimization strategy by a general approach to enhance improving potential of dew-point evaporative coolers. Energy Convers. Manag. 2019, 188, 177-213. [CrossRef]

56. Zemero, B.R.; Tostes, M.E.d.L.; Bezerra, U.H.; Batista, V.d.S.; Carvalho, C.C.M. Methodology for Preliminary Design of Buildings Using Multi-Objective Optimization Based on Performance Simulation. J. Sol. Energy Eng. 2019, 141, 040801. [CrossRef]

57. Yi, Y.K. Building facade multi-objective optimization for daylight and aesthetical perception. Build. Environ. 2019, 156, 178-190. [CrossRef]

58. Hong, T.; Kim, J.; Lee, M. A multi-objective optimization model for determining the building design and occupant behaviors based on energy, economic, and environmental performance. Energy 2019, 174, 823-834. [CrossRef]

59. Kirimtat, A.; Krejcar, O.; Ekici, B.; Tasgetiren, M.F. Multi-objective energy and daylight optimization of amorphous shading devices in buildings. Sol. Energy 2019, 185, 100-111. [CrossRef]

60. Ascione, F.; Bianco, N.; Mauro, G.M.; Napolitano, D.F. Building envelope design: Multi-objective optimization to minimize energy consumption, global cost and thermal discomfort. Application to different Italian climatic zones. Energy 2019, 174, 359-374. [CrossRef]

61. Zhai, Y.; Wang, Y.; Huang, Y.; Meng, X. A multi-objective optimization methodology for window design considering energy consumption, thermal environment and visual performance. Renew. Energy 2019, 134, 1190-1199. [CrossRef]

62. Si, B.; Wang, J.; Yao, X.; Shi, X.; Jin, X.; Zhou, X. Multi-objective optimization design of a complex building based on an artificial neural network and performance evaluation of algorithms. Adv. Eng. Inform. 2019, 40, 93-109. [CrossRef]

63. Sharif, S.A.; Hammad, A. Simulation-based multi-objective optimization of institutional building renovation considering energy consumption, life-cycle cost and life-cycle assessment. J. Build. Eng. 2019, 21, 429-445. [CrossRef]

64. Fang, Y.; Cho, S. Design optimization of building geometry and fenestration for daylighting and energy performance. Sol. Energy 2019, 191, 7-18. [CrossRef]

65. Sohani, A.; Sayyaadi, H.; Azimi, M. Employing static and dynamic optimization approaches on a desiccant-enhanced indirect evaporative cooling system. Energy Convers. Manag. 2019, 199, 112017. [CrossRef]

66. Lu, Y.; Wang, S.; Zhao, Y.; Yan, C. Renewable energy system optimization of low/zero energy buildings using single-objective and multi-objective optimization methods. Energy Build. 2015, 89, 61-75. [CrossRef]

67. Delgarm, N.; Sajadi, B.; Kowsary, F.; Delgarm, S. Multi-objective optimization of the building energy performance: A simulationbased approach by means of particle swarm optimization (PSO). Appl. Energy 2016, 170, 293-303. [CrossRef] 
68. Delgarm, N.; Sajadi, B.; Delgarm, S. Multi-objective optimization of building energy performance and indoor thermal comfort: A new method using artificial bee colony (ABC). Energy Build. 2016, 131, 42-53. [CrossRef]

69. Delgarm, N.; Sajadi, B.; Delgarm, S.; Kowsary, F. A novel approach for the simulation-based optimization of the buildings energy consumption using NSGA-II: Case study in Iran. Energy Build. 2016, 127, 552-560. [CrossRef]

70. Xiong, J.; Tzempelikos, A.; Bilionis, I.; Karava, P. A personalized daylighting control approach to dynamically optimize visual satisfaction and lighting energy use. Energy Build. 2019, 193, 111-126. [CrossRef]

71. Durmus, D.; Abdalla, D.; Duis, A.; Davis, W. Spectral optimization to minimize light absorbed by artwork. Leukos 2020, 16, 45-54. [CrossRef]

72. Sohani, A.; Sayyaadi, H.; Mohammadhosseini, N. Comparative study of the conventional types of heat and mass exchangers to achieve the best design of dew point evaporative coolers at diverse climatic conditions. Energy Convers. Manag. 2018, 158, 327-345. [CrossRef]

73. Dadsetani, R.; Sheikhzadeh, G.A.; Safaei, M.R.; Alnaqi, A.A.; Amiriyoon, A. Exergoeconomic optimization of liquefying cycle for noble gas argon. Heat Mass Transf. 2019, 55, 1995-2007. [CrossRef]

74. Alamian, R.; Shafaghat, R.; Safaei, M.R. Multi-objective optimization of a pitch point absorber wave energy converter. Water 2019, 11, 969. [CrossRef]

75. Moradikazerouni, A.; Hajizadeh, A.; Safaei, M.R.; Afrand, M.; Yarmand, H.; Zulkifli, N.W.B.M. Assessment of thermal conductivity enhancement of nano-antifreeze containing single-walled carbon nanotubes: Optimal artificial neural network and curve-fitting. Phys. A Stat. Mech. Its Appl. 2019, 521, 138-145. [CrossRef]

76. Afrand, M.; Najafabadi, K.N.; Sina, N.; Safaei, M.R.; Kherbeet, A.S.; Wongwises, S.; Dahari, M. Prediction of dynamic viscosity of a hybrid nano-lubricant by an optimal artificial neural network. Int. Commun. Heat Mass Transf. 2016, 76, 209-214. [CrossRef]

77. Yağlı, H.; Koç, Y.; Kalay, H. Optimisation and exergy analysis of an organic Rankine cycle (ORC) used as a bottoming cycle in a cogeneration system producing steam and power. Sustain. Energy Technol. Assess. 2021, 44, 100985.

78. Köse, Ö.; Koç, Y.; Yağlı, H. Energy, exergy, economy and environmental (4E) analysis and optimization of single, dual and triple configurations of the power systems: Rankine Cycle/Kalina Cycle, driven by a gas turbine. Energy Convers. Manag. 2021, 227, 113604. [CrossRef]

79. Razmi, A.R.; Arabkoohsar, A.; Nami, H. Thermoeconomic analysis and multi-objective optimization of a novel hybrid absorption/recompression refrigeration system. Energy 2020, 210, 118559. [CrossRef]

80. Yağlı, H.; Koç, Y.; Koç, A.; Görgülü, A.; Tandiroğlu, A. Parametric optimization and exergetic analysis comparison of subcritical and supercritical organic Rankine cycle (ORC) for biogas fuelled combined heat and power (CHP) engine exhaust gas waste heat. Energy 2016, 111, 923-932. [CrossRef]

81. Hoseinzadeh, S.; Stephan Heyns, P. Advanced Energy, Exergy, and Environmental (3E) Analyses and Optimization of a Coal-Fired 400 MW Thermal Power Plant. J. Energy Resour. Technol. 2021, 143, 082106. [CrossRef]

82. Hoseinzadeh, S.; Yargholi, R.; Kariman, H.; Heyns, P.S. Exergoeconomic analysis and optimization of reverse osmosis desalination integrated with geothermal energy. Environ. Prog. Sustain. Energy 2020, 39, e13405. [CrossRef]

83. Sohani, A.; Naderi, S.; Torabi, F.; Sayyaadi, H.; Golizadeh Akhlaghi, Y.; Zhao, X.; Talukdar, K.; Said, Z. Application based multi-objective performance optimization of a proton exchange membrane fuel cell. J. Clean. Prod. 2020, 252, 119567. [CrossRef]

84. Nami, H.; Mahmoudi, S.M.S.; Nemati, A. Exergy, economic and environmental impact assessment and optimization of a novel cogeneration system including a gas turbine, a supercritical $\mathrm{CO}_{2}$ and an organic Rankine cycle (GT-HRSG/SCO 2$)$. Appl. Therm. Eng. 2017, 110, 1315-1330. [CrossRef]

85. Keshavarzzadeh, A.H.; Ahmadi, P.; Safaei, M.R. Assessment and optimization of an integrated energy system with electrolysis and fuel cells for electricity, cooling and hydrogen production using various optimization techniques. Int. J. Hydrog. Energy 2019, 44, 21379-21396. [CrossRef]

86. Sohani, A.; Naderi, S.; Torabi, F. Comprehensive comparative evaluation of different possible optimization scenarios for a polymer electrolyte membrane fuel cell. Energy Convers. Manag. 2019, 191, 247-260. [CrossRef] 